\title{
Synthesis and Characterization of binuclear Pt(IV) Complexes and tetranuclear Mixed Valence Complexes of Platinum(II)-Platinum(IV).
}

José M. Casas*, Beatriz E. Diosdado, Juan Forniés, M. Ángeles García-Monforte, Raquel Laporta, Antonio Martín, Milagros Tomás.

Departamento de Química Inorgánica, Instituto de Síntesis Química y Catálisis Homogénea (ISQCH), Universidad de Zaragoza-C.S.I.C., E-50009 Zaragoza, Spain.

\begin{abstract}
The binuclear platinum(IV) complexes $\left[\mathrm{NBu}_{4}\right]_{2}\left[\mathrm{Pt} \mathrm{IV}_{2}(\mu-\mathrm{Cl})_{2}\left(\mathrm{C}_{6} \mathrm{~F}_{5}\right)_{4} \mathrm{Cl}_{4}\right]$ (2) and $\left[\mathrm{Pt} \mathrm{IV}_{2}\left(\mu-\mathrm{C}_{8} \mathrm{H}_{6} \mathrm{~N}_{4}\right)_{2}\left(\mathrm{C}_{6} \mathrm{~F}_{5}\right)_{4} \mathrm{Cl}_{4}\right](4)$ have been synthesized by oxidative addition of chlorine to the binuclear platinum(II) species, but $\left[\mathrm{NBu}_{4}\right]_{2}\left[\mathrm{Pt} \mathrm{IV}_{2}(\mu-\mathrm{OH})_{2}\left(\mathrm{C}_{6} \mathrm{~F}_{5}\right)_{4} \mathrm{Cl}_{4}\right]$ (3) has been synthesized by substitution of the chloride bridges of the platinum(IV) complex. The square planar platinum environments of the Pt(II) starting materials change, as expected, to Pt(IV) octahedral environments with the chloride ligands in trans-position. Not important changes in the $\mathrm{Pt}-\mathrm{X}(\mathrm{X}=\mathrm{Cl}$ bridge, $\mathrm{OH})$ interatomic distances are produced because of the oxidation.

Depending on the size of the bridging ligands and also probably the anionic character of the diplatinum(IV) complexes, the apical chloride ligands can still act as bridges toward other Pt centres. Thus, the organometallic tetra-nuclear mixed-valence platinum(IV)-platinum(II) complexes with formulas $\left[\mathrm{NBu}_{4}\right]_{2}\left[\left\{\mathrm{Pt}^{\mathrm{IV}}(\mu-\mathrm{X})\left(\mathrm{C}_{6} \mathrm{~F}_{5}\right)_{2}\right\}_{2}(\mu-\mathrm{Cl})_{4}\left\{\mathrm{Pt}^{\mathrm{II}}\left(\mathrm{C}_{6} \mathrm{~F}_{5}\right)_{2}\right\}_{2}\right][\mathrm{X}=\mathrm{Cl}(\mathbf{5})$, $\mathrm{OH}(6)]$ were obtained by reaction of 2 and 3 with cis- $\left[\mathrm{Pt}^{\mathrm{II}}\left(\mathrm{C}_{6} \mathrm{~F}_{5}\right)_{2}(\mathrm{thf})_{2}\right]$. The structures of complexes 2, 4 and 6 have been determined by single-crystal X-ray diffraction studies. These crystal structures confirm that the oxidative addition of the chlorine molecule to the platinum(II) complexes $\mathbf{2}$ and $\mathbf{3}$ takes place on the axial positions of the platinum centers suggesting a $\mathrm{SN}_{2}$ mechanism. On the other hand, the central core of the anion of $\mathbf{6}$ has a chair like conformation and the long $\mathrm{Pt} \cdots \mathrm{Pt}$ distances ( $>3.2 \AA$ ) clearly exclude any $\mathrm{Pt}-\mathrm{Pt}$ interaction.
\end{abstract}

On the other hand, cis- $\left[\left(\mathrm{C}_{6} \mathrm{~F}_{5}\right)_{2} \mathrm{Pt}\left(\mu-\mathrm{C}_{8} \mathrm{H}_{6} \mathrm{~N}_{4}\right) \mathrm{Pt}\left(\mathrm{C}_{6} \mathrm{~F}_{5}\right)_{2}\right]$ (1) can be reduced either electrochemically or by reacting with $\left[\mathrm{CoCp}_{2}\right]$ to the anion $\left[\mathrm{Pt}_{2}\left(\mu-\mathrm{C}_{8} \mathrm{H}_{6} \mathrm{~N}_{4}\right)\left(\mathrm{C}_{6} \mathrm{~F}_{5}\right)_{4}\right]^{-}$which in the last case, can be isolated as complex 7. According to the EPR studies the anion is not a 
mixed $\mathrm{Pt}(\mathrm{II}) / \mathrm{Pt}(\mathrm{I})$ compound but a binuclear $\mathrm{Pt}(\mathrm{II})$ derivative with the anion $\left[\mathrm{C}_{8} \mathrm{H}_{6} \mathrm{~N}_{4}\right]^{-}$as bridging ligand.

\section{Introduction}

Platinum(IV) complexes are usually obtained by oxidation of platinum(II) precursors [1] with halogens $\left(\mathrm{Cl}_{2}, \mathrm{Br}_{2}, \mathrm{I}_{2}, \mathrm{PhICl}_{2}\right)$ [2-5] or organic halogenated molecules (MeI, EtI, $\mathrm{PhCH}_{2} \mathrm{Br}, \ldots$... [6-8]. The oxidative addition process over mononuclear platinum(II) complex produces, in most cases, the mononuclear platinum(IV) species $[5,9,10]$ but in some occasions complexes which show cubane-like structures [11,12], oligomer chains [7,13] or supramolecular polymers [14] are obtained. Only a few binuclear platinum(IV) complexes containing two octahedral Pt(IV) environments sharing an edge or a face have been reported and structurally characterized [15-20].

Mixed-valence platinum(II)-platinum(IV) complexes are also known and have been structurally characterized [21-42]. Most of these compounds display linear structures with $\left[\cdots \mathrm{Pt}^{\mathrm{II}} \mathrm{L}_{4} \cdots \mathrm{X}-\mathrm{Pt}^{\mathrm{IV}} \mathrm{L}_{4}-\mathrm{X} \cdots\right]_{\mathrm{n}}(\mathrm{X}=\mathrm{Cl}, \mathrm{Br}, \mathrm{I})$ chains, that can be single (1D), ladder type or double (2D) laying along one crystallographic axis in which square-planar coordinated $\mathrm{Pt}(\mathrm{II})$ ions and octahedral coordinated Pt(IV) ions are alternately arranged and that have drawn much attention because of their nonlinear optical and luminescence properties [21-23,34,35]. Also, a small amount of discrete bi-, tri-, and tetranuclear mixed-valence platinum(II)platinum(IV) complexes have been described [24-30,33,36-42].

On the other hand, partial oxidative addition of binuclear Pt(II) complexes allows to prepare the binuclear platinum(II)-platinum(IV) anions $\left[\mathrm{I}_{4} \mathrm{Pt}^{\mathrm{IV}}(\mu-\mathrm{I})_{2} \mathrm{Pt}^{\mathrm{II}} \mathrm{I}_{2}\right]^{2-}$ [21-27], $[\mathrm{NBu} 4]\left[\left(\mathrm{C}_{6} \mathrm{~F}_{5}\right)_{2} \mathrm{Pt}^{\mathrm{II}}\left(\mu-\mathrm{PPh}_{2}\right)_{2} \mathrm{Pt}^{\mathrm{IV}}\left(\kappa^{2}, \mathrm{~N}, \mathrm{C}-\mathrm{C}_{13} \mathrm{H}_{8} \mathrm{~N}\right) \mathrm{I}_{2}\right] \quad[38,39], \quad[\mathrm{NBu} 4]_{2}\left[\mathrm{Pt}^{\mathrm{IV}} \mathrm{Pt}^{\mathrm{II}}{ }_{3}\left(\mathrm{C}_{6} \mathrm{Cl}_{5}\right)_{8}(\mu-\right.$ $\left.\mathrm{OH})_{2}\left(\mu_{3}-\mathrm{OH}\right)_{2}\right][40]$ and $\left[\mathrm{Pt}_{2}\left(\mathrm{C}_{6} \mathrm{~F}_{5}\right)_{4}\left(\mathrm{C}_{5} \mathrm{H}_{4} \mathrm{NS}\right)_{2} \mathrm{X}\right](\mathrm{X}=\mathrm{Cl}, \mathrm{Br}, \mathrm{I})$. These later are interesting since they have been synthesized as intermediates in the $\mathrm{Pt}(\mathrm{II})-\mathrm{Pt}(\mathrm{II})$ to $\mathrm{Pt}(\mathrm{IV})-\mathrm{Pt}(\mathrm{IV})$ sequence [41]. A singular oxidative addition reaction has been described from [Pt( $\left.\left.\mathrm{PEt}_{3}\right)_{3}\right]$ and 1,2-disilylbenzene in $1: 1$ ratio at $60^{\circ} \mathrm{C}$ yielding the binuclear neutral complex $\left[\left(\mathrm{PEt}_{3}\right)_{2} \mathrm{Pt}^{\mathrm{II}}(\mu-\right.$ $\left.\mathrm{HSiC}_{6} \mathrm{H}_{4} \mathrm{SiH}_{2}\right)_{2} \mathrm{Pt}^{\mathrm{IV}}\left(\mathrm{PEt}_{3}\right)_{2}$ ] [28]. In addition, $\left[\mathrm{Pt}_{3} \mathrm{X}_{12}\right]^{2-}(\mathrm{X}=\mathrm{Cl}, \mathrm{Br})$ are trinuclear platinum(II)-platinum(IV) mixed valence complexes [26], and they consist in three linearly arranged platinum atoms $\left(\mathrm{Pt}^{\mathrm{IV}}-\mathrm{Pt}^{\mathrm{II}}-\mathrm{Pt}^{\mathrm{IV}}\right)$ connected by halo-bridging ligands. The chloridecompound was isolated from a mixture of Pt(IV) complexes, probably being the result of the 
reductive elimination of $\mathrm{Cl}_{2}$ from the $\left[\mathrm{Pt}_{3} \mathrm{Cl}_{14}\right]^{2-}$ anion at the central platinum atom, while the bromide derivative has been deliberately synthesized by reaction between $\left[\mathrm{PtBr}_{6}\right]^{2-}$ and $\left[\mathrm{PtBr}_{4}\right]^{2-}$ in 2:1 ratio, Very recently, Belli Dell'Amico et al. have published the synthesis and structural characterization of the pentanuclear mixed-valence $\mathrm{Pt}(\mathrm{II})-\mathrm{Pt}(\mathrm{IV})$ complex anion $\left[\mathrm{Pt}_{5} \mathrm{Cl}_{20}\right]^{2-}$ which has been prepared by using $\mathrm{Pt}(\mathrm{IV})$ derivatives as starting materials [42].

Puddephatt and co-workers synthesized some platinum(II)-platinum(IV) cationic complexes from binuclear platinum(II) complexes by oxidative addition of halogen over one of the two platinum(II) atoms, and the resulting binuclear products, which have three bridging ligands, suffer an intramolecular transfer reaction of a methyl group [29]. More recently Puddephat has described a strategy to synthesize organoplatinum dendrimers by using a reagent containing alkyl halide and diimine functionalities. The successive growth of the nuclearity needs the coordination of one platinum(II) fragment to the non bonded diimine part in a previous step to the new oxidative addition; so the process involves as intermediates mixed-valence platinum(II)-platinum(IV) complexes [7,36].

In this paper we describe the synthesis of three new neutral and anionic binuclear Pt(IV) complexes, two of which can be used as starting materials for the preparation of the first tetranuclear platinum(II)-platinum(IV) mixed-valence complexes. These anionic organometallic platinum(II)-platinum(IV) complexes are synthesized by addition of the stoicheiometric amount of a platinum(II) reagent $\left[\right.$ cis- $\left[\mathrm{Pt}\left(\mathrm{C}_{6} \mathrm{~F}_{5}\right)_{2}(\mathrm{thf})_{2}\right]$ to binuclear platinum(IV) complexes in a different way from the route used by Thiele and coworkers [partial oxidation of the correspondent platinum(II) anions with $\left.\mathrm{X}_{2}(\mathrm{X}=\mathrm{Br}, \mathrm{I})\right][26,27]$ or by Puddephatt and coworkers (in which an oxidative addition to binuclear platinum(II) complexes and further group transfer between the platinum atoms are involved) [29,30].

\section{Experimental section}

General methods. C, H, and N analyses were carried out with a Perkin-Elmer 240B microanalyzer. IR spectra were recorded over the 4000-200 $\mathrm{cm}^{-1}$ range on a Perkin Elmer Spectrum One from Nujol mulls between polyethylene sheets or on a Perkin Elmer Spectrum 100 FT-IR spectrometer with an Universal ATR Sampling Accessory. ${ }^{1} \mathrm{H}$ and ${ }^{19} \mathrm{~F}$ NMR spectra were recorded on a Varian Unity-300 or Gemini or a BRUKER AV-400 in $\mathrm{CDCl}_{3}$, 
$\mathrm{CD}_{2} \mathrm{Cl}_{2}$ or $\mathrm{d}_{6}$-acetone solutions. [ $\left.\mathrm{NBu}_{4}\right]_{2}\left[\mathrm{Pt}_{2}(\mu-\mathrm{Cl})_{2}\left(\mathrm{C}_{6} \mathrm{~F}_{5}\right)_{4}\right]$ [43] was prepared as described elsewhere. The 2,2' bipyrimidine ligand was purchased and used as received from Lancaster.

Electrochemical studies were carried out using an EG\&G model 273 potentiostat in conjunction with a three-electrode cell, in which the working electrode was a platinum disc, the auxiliary electrode a platinum wire, and the reference was an aqueous saturated calomel electrode (SCE) separated from the test solution by a fine-porosity frit and an agar bridge saturated with $\mathrm{KCl}$. Solutions were $5 \times 10^{-4} \mathrm{~mol} \mathrm{dm}^{-3}$ in the test compound and $0.1 \mathrm{~mol} \mathrm{dm}^{-3}$ in $\left[\mathrm{NBu}_{4}\right]\left[\mathrm{PF}_{6}\right]$ as the supporting electrolyte. The solutions were saturated with Ar by bubbling them with this gas before each experiment. At the end of each electrochemical experiment, $\left[\mathrm{Fe}\left(\eta^{5}-\mathrm{C}_{5} \mathrm{H}_{5}\right)_{2}\right]$ was added to the solution as an internal standard for potential measurements. Under the conditions used, the $E^{\mathrm{o}}$ value for the couple $\left[\mathrm{Fe}\left(\eta^{5}-\mathrm{C}_{5} \mathrm{H}_{5}\right)_{2}\right]^{+} /$ $\left[\mathrm{Fe}\left(\eta^{5}-\mathrm{C}_{5} \mathrm{H}_{5}\right)_{2}\right]$ was $0.47 \mathrm{~V}$. Controlled potential electrochemistry (CPE) was carried out in a two-compartment three electrode cell with a platinum gauze working and counter electrodes in compartments separated by a glass frit; a saturated calomel electrode (SCE) separated from the test solution by a fine-porosity frit and an agar bridge saturated with $\mathrm{KCl}$ was used as reference.

EPR data were taken in a Bruker ESP300 spectrometer. The magnetic field was measured with a Bruker ER035M gaussmeter. A Hewlett-Packard HP5350B frequency counter was used to determine the microwave frequency.

Preparation of cis- $\left[\left(\mathbf{C}_{6} \mathbf{F}_{5}\right)_{2} \mathbf{P t}\left(\boldsymbol{\mu}-\mathbf{C}_{8} \mathbf{H}_{6} \mathbf{N}_{4}\right) \mathbf{P t}\left(\mathbf{C}_{6} \mathbf{F}_{5}\right)_{2}\right](\mathbf{1}) .0 .013 \mathrm{~g}(0.085 \mathrm{mmol})$ of 2, 2'-bipyrimidine were added to a solution of cis-[Pt( $\left.\left.\mathrm{C}_{6} \mathrm{~F}_{5}\right)_{2}(\mathrm{thf})_{2}\right](0.115 \mathrm{~g}, 0.171 \mathrm{mmol})$ in 15 $\mathrm{ml}$ of $\mathrm{CHCl}_{3}$. Instantaneously, a solid precipitated and the suspension was stirred at room temperature for $15 \mathrm{~min}$. Then the solution was evaporated to $5 \mathrm{~mL}$ approximately, and the resulting dark orange solid was filtered off and washed with $n$-hexane. (91\% yield). Anal. Found (Calcd. for $\mathrm{C}_{32} \mathrm{H}_{6} \mathrm{~N}_{4} \mathrm{~F}_{20} \mathrm{Pt}_{2}$ ): C, 31.31 (31.59); H, 0.72 (0.50); N, 4.80 (4.60). IR $\left(\mathrm{cm}^{-1}\right): \mathrm{C}_{6} \mathrm{~F}_{5} \mathrm{X}$-sensitive mode [44] $815 \mathrm{~s}, 806 \mathrm{~s}$; other, v(C-F), $965 \mathrm{~s}$; $\mathrm{C}_{8} \mathrm{H}_{6} \mathrm{~N}_{4}, 1586 \mathrm{w}$, $1557 \mathrm{~m}, 1503 \mathrm{~s}, 1419 \mathrm{~m}, 754 \mathrm{~m} ;{ }^{1} \mathrm{H}$ NMR (room temperature), d6-acetone; $\delta / p p m: 9.34$ $\operatorname{ppm}(\mathrm{d}, 4 \mathrm{H}), 8.34 \mathrm{ppm}(\mathrm{t}, 2 \mathrm{H}) .{ }^{19} \mathrm{~F}$ NMR (room temperature), $\mathrm{d}_{6}$-acetone; $\delta / \mathrm{ppm}:-114.93$ (d, $\left.4 \mathrm{Fo},{ }^{3} J_{\mathrm{Pt}-\mathrm{Fo}}=459.82 \mathrm{~Hz}\right),-115.01\left(\mathrm{~d}, 4 \mathrm{Fo},{ }^{3} J_{\mathrm{Pt}-\mathrm{Fo}}=460.95 \mathrm{~Hz}\right),-158.50\left(\mathrm{t}, 4 \mathrm{Fp},{ }^{4} J_{\mathrm{F} p-\mathrm{Fo}}=\right.$ $38.65 \mathrm{~Hz}),-161.00(\mathrm{~m}, 8 \mathrm{Fm}) . \mathrm{FAB}+(\mathrm{m} / \mathrm{z}):\left[\mathrm{Pt}_{2}\left(\mathrm{C}_{6} \mathrm{~F}_{5}\right)_{4}\left(\mathrm{C}_{8} \mathrm{H}_{6} \mathrm{~N}_{4}\right)\right]: 1216$. 
Preparation of $\left[\mathrm{NBu}_{4}\right]_{2}\left[\mathrm{Pt}_{2}\left(\mu-\mathrm{Cl}_{2}\left(\mathrm{C}_{6} \mathbf{F}_{5}\right)_{4} \mathrm{Cl}_{4}\right]\right.$ (2). To a solution of $\left[\mathrm{NBu}_{4}\right]_{2}\left[\mathrm{Pt}_{2}(\mu-\mathrm{Cl})_{2}\left(\mathrm{C}_{6} \mathrm{~F}_{5}\right)_{4}\right](0.150 \mathrm{~g}, 0.093 \mathrm{mmol})$ in $\mathrm{Me}_{2} \mathrm{CO}(10 \mathrm{~mL}), \mathrm{NBu} 4 \mathrm{Cl}(0.052 \mathrm{~g}$, $0.186 \mathrm{mmol}$ ) and $\mathrm{a} \mathrm{Cl}_{2} / \mathrm{CCl}_{4}$ solution in excess were added. After 15 minutes stirring at room temperature, the resulting yellow solution was evaporated to dryness. The residue was washed with water $(3 \times 10 \mathrm{~mL})$, an after that the residue was dissolved in $\mathrm{CH}_{2} \mathrm{Cl}_{2}(10 \mathrm{ml})$ and treated with $\mathrm{MgSO}_{4}$, which after some minutes stirring was separated by filtration through celite. The resulting $\mathrm{CH}_{2} \mathrm{Cl}_{2}$ solution was evaporated to dryness and the residue was treated with $\mathrm{Et}_{2} \mathrm{O}$ yieding a pale-yellow solid (2) which was filtered off and air dried. Yield: 61\%. Anal. Found (Calcd. for $\mathrm{C}_{56} \mathrm{H}_{72} \mathrm{Cl}_{6} \mathrm{~F}_{20} \mathrm{~N}_{2} \mathrm{Pt}_{2}$ ): C, 38.43 (38.20); H, 3.81 (4.14); N, 1.53 (1.60). IR (cm-1): $\mathrm{C}_{6} \mathrm{~F}_{5}$ : v(C-F), 966 vs; X-sensitive mode [44], $790 \mathrm{~m}$; others, $2963 \mathrm{~m}, 2876 \mathrm{w}, 1504$ s, 1458 sh, 1444 vs, $1380 \mathrm{w}, 1367 \mathrm{w}, 1261 \mathrm{w}, 1105 \mathrm{w}, 1066 \mathrm{~s}, 1028 \mathrm{w}, 1002 \mathrm{w} ;\left(\mathrm{NBu}_{4}^{+}\right), 879 \mathrm{w}, 739$ w; $v(\mathrm{Pt}-\mathrm{Cl})_{\text {terminal, }} 327 \mathrm{~s} ; \mathrm{v}(\mathrm{Pt}-\mathrm{Cl})_{\text {bridge }} 264$ vs. ${ }^{19} \mathrm{~F} \mathrm{RMN}$ en $\mathrm{CD}_{2} \mathrm{Cl}_{2}$ (bruker $\left.400 \mathrm{MHz}\right) \delta / \mathrm{ppm}$ : $-112.78 \mathrm{ppm}\left(\mathrm{F}_{o}, \mathrm{~d}, 4 \mathrm{~F}\right),{ }^{3} \mathrm{~J}_{\mathrm{Fm}-\mathrm{Fo}}=24.69 \mathrm{~Hz},{ }^{3} \mathrm{JPt}_{\mathrm{P}-\mathrm{Fo}}=102.14 \mathrm{~Hz} ;-115.77 \mathrm{ppm}\left(\mathrm{F}_{o}, \mathrm{~d}, 4 \mathrm{~F}\right)$, ${ }^{3} J_{\mathrm{Fm}-\mathrm{Fo}}=24.89 \mathrm{~Hz},{ }^{3} J_{\mathrm{Pt}-\mathrm{Fo}}=112.97 \mathrm{~Hz} ;-164.43 \mathrm{ppm}\left(\mathrm{F}_{p}, \mathrm{t}, 4 \mathrm{~F}\right) ;-166.59 \mathrm{ppm}\left(\mathrm{F}_{m}, \mathrm{~m}, 4 \mathrm{~F}\right)$; $-167.29 \mathrm{ppm}\left(\mathrm{F}_{m}, \mathrm{~m}, 4 \mathrm{~F}\right)$.

Preparation of $\left[\mathrm{NBu}_{4}\right]_{2}\left[\mathrm{Pt}_{2}(\boldsymbol{\mu}-\mathrm{OH})_{2}\left(\mathrm{C}_{6} \mathbf{F}_{5}\right)_{4} \mathbf{C l}_{4}\right]$ (3). To a solution of $\left[\mathrm{NBu}_{4}\right]_{2}\left[\mathrm{Pt}_{2}(\mu-\right.$ $\left.\mathrm{Cl})_{2}\left(\mathrm{C}_{6} \mathrm{~F}_{5}\right)_{4} \mathrm{Cl}_{4}\right]$ (2) $(0.073 \mathrm{~g}, 0.041 \mathrm{mmol})$ in $\mathrm{Me}_{2} \mathrm{CO}(10 \mathrm{~mL}), \mathrm{NBu} 4 \mathrm{OH}\left(1 \mathrm{M}\right.$ in $\left.\mathrm{H}_{2} \mathrm{O}\right)(66$ $\mathrm{mg}, 0.082 \mathrm{mmol}$ ) was added. After 2 hours stirring at room temperature, the solvent was evaporated to dryness. The residue was washed with water $(3 \times 10 \mathrm{~mL})$, after that the residue was dissolved in $\mathrm{CH}_{2} \mathrm{Cl}_{2}(10 \mathrm{ml})$ and treated with $\mathrm{MgSO}_{4}$, which after some minutes stirring was separated by filtration through celite. The resulting $\mathrm{CH}_{2} \mathrm{Cl}_{2}$ solution was evaporated to dryness and the residue was washed with $\mathrm{iPrOH}(3 \times 1 \mathrm{ml})$ and $\mathrm{Et}_{2} \mathrm{O}$ giving a yellow oily residue which could be spectroscopically identified as $\left[\mathrm{NBu}_{4}\right]_{2}\left[\mathrm{Pt}_{2}(\mu-\mathrm{OH})_{2}\left(\mathrm{C}_{6} \mathrm{~F}_{5}\right)_{4} \mathrm{Cl}_{4}\right]$ (3). IR $\left(\mathrm{cm}^{-1}\right): \mathrm{C}_{6} \mathrm{~F}_{5}: \mathrm{v}(\mathrm{C}-\mathrm{F}), 965 \mathrm{vs} ; \mathrm{X}$-sensitive mode [44], $790 \mathrm{~m}$; others, $2963 \mathrm{~m}, 2876 \mathrm{w}, 1504$ m, 1459 s, 1380 m, 1361 m, 1065 s, 1028 w, 1002 w; $\left(\mathrm{NBu}_{4}^{+}\right), 879$ w, 739 w; v(Pt-Cl)terminal, $337 \mathrm{~m}$; v(O-H), 3585 w. ${ }^{19} \mathrm{~F}$ RMN en $\mathrm{CD}_{2} \mathrm{Cl}_{2}$ (bruker $\left.400 \mathrm{MHz}\right) \delta / \mathrm{ppm}$ : -117.67 ppm (Fo, d, $4 \mathrm{~F}),{ }^{3} J_{\mathrm{Fm}-\mathrm{Fo}}=25.01 \mathrm{~Hz},{ }^{3} J_{\mathrm{Pt}-\mathrm{Fo}}=115.86 \mathrm{~Hz} ;-121.03 \mathrm{ppm}\left(\mathrm{F}_{o}, \mathrm{~d}, 4 \mathrm{~F}\right),{ }^{3} J_{\mathrm{Fm}-\mathrm{Fo}}=30.01 \mathrm{~Hz}$, ${ }^{3} J_{\mathrm{Pt}-\mathrm{Fo}}=91.84 \mathrm{~Hz} ;-169.04 \mathrm{ppm}\left(\mathrm{F}_{p}, \mathrm{t}, 4 \mathrm{~F}\right) ;-169.99 \mathrm{ppm}\left(\mathrm{F}_{m}, \mathrm{~m}, 4 \mathrm{~F}\right) ;-170.75 \mathrm{ppm}\left(\mathrm{F}_{\mathrm{m}}, \mathrm{m}\right.$, $4 \mathrm{~F})$. 
Preparation of $\left[\mathbf{P t}_{\mathbf{2}}\left(\boldsymbol{\mu}-\mathbf{C}_{\mathbf{8}} \mathbf{H}_{6} \mathbf{N}_{4}\right) \mathbf{C l}_{\mathbf{4}}\left(\mathbf{C}_{6} \mathbf{F}_{5}\right)_{4}\right]$ (4). To a suspension of $\mathbf{1}(0.030 \mathrm{~g}, 0.025$ mmol) in $10 \mathrm{ml}$ of $\mathrm{CH}_{2} \mathrm{Cl}_{2}, 5 \mathrm{ml}$ of a saturated solution of $\mathrm{Cl}_{2}$ in $\mathrm{CCl}_{4}$ were added. The orange suspension changed to a yellow solution. After $14 \mathrm{~h}$ stirring at room temperature the resulting pale yellow suspension was evaporated to dryness and the yellow residue was washed with $n$ hexane and filtered. $77 \%$ yield. Anal. Found (Calcd. for $\mathrm{C}_{32} \mathrm{H}_{6} \mathrm{~N}_{4} \mathrm{Cl}_{4} \mathrm{~F}_{20} \mathrm{Pt}_{2}$ ): $\mathrm{C}, 28.09$ (28.29); H, 0.45 (0.44); N, 4.20 (4.12). IR ( $\left.\mathrm{cm}^{-1}\right)$ : $\mathrm{C}_{6} \mathrm{~F}_{5}$ X-sensitive mode [44] $809 \mathrm{~s}, 800 \mathrm{~s}$; v(C-F) 974 vs; $\mathrm{C}_{8} \mathrm{H}_{6} \mathrm{~N}_{4}, 1594$ vs, 1520 vs, 1425 vs, 821 m, 754 s; v(Pt-Cl) 354 s. ${ }^{1} \mathrm{H}$ NMR (room temperature), $\mathrm{d}_{6}$-acetone; $\delta / \mathrm{ppm}: 9.78(\mathrm{t}, 4 \mathrm{H}), 8.81(\mathrm{~m}, 2 \mathrm{H}) .{ }^{19} \mathrm{~F}$ NMR (room temperature), $\mathrm{d}_{6}$-acetone; $\delta / \mathrm{ppm}:-118.04\left(\mathrm{~d}, 4 \mathrm{~F}_{0},{ }^{3} J_{\mathrm{Pt}-\mathrm{Fo}}=103.35 \mathrm{~Hz}\right),-118.24\left(\mathrm{~d}, 4 \mathrm{~F}_{0},{ }^{3} J_{\mathrm{Pt}-\mathrm{Fo}}\right.$ $=102.39 \mathrm{~Hz}),-158.80\left(\mathrm{~m}, 4 \mathrm{~F}_{p}\right),-162.79\left(\mathrm{~m}, 4 \mathrm{~F}_{\mathrm{m}}\right),-163.99\left(\mathrm{~m}, 4 \mathrm{~F}_{\mathrm{m}}\right)$.

Preparation of $\left[\mathrm{NBu}_{4}\right]_{2}\left[\left\{\operatorname{Pt}(\mu-\mathrm{Cl})\left(\mathrm{C}_{6} \mathrm{~F}_{5}\right)_{2}\right\}_{2}(\mu-\mathrm{Cl})_{4}\left\{\operatorname{Pt}\left(\mathrm{C}_{6} \mathbf{F}_{5}\right)_{2}\right\}_{2}\right]$ (5). To a solution of $\left[\mathrm{NBu}_{4}\right]_{2}\left[\mathrm{Pt}_{2}(\mu-\mathrm{Cl})_{2}\left(\mathrm{C}_{6} \mathrm{~F}_{5}\right)_{4} \mathrm{Cl}_{4}\right]$ (2) $(0.100 \mathrm{~g}, 0.057 \mathrm{mmol})$ in $\mathrm{CH}_{2} \mathrm{Cl}_{2}(40 \mathrm{~mL})$, cis$\left[\mathrm{Pt}\left(\mathrm{C}_{6} \mathrm{~F}_{5}\right)_{2}(\mathrm{thf})_{2}\right](0.076 \mathrm{~g}, 0.114 \mathrm{mmol})$ was added. After $5 \mathrm{~min}$ stirring at room temperature, the resulting red solution was evaporated to dryness. The residue was treated with $n$-hexane $(15 \mathrm{~mL})$ yielding a red solid (5) which was filtered off. Yield: 58\%. Anal. Found (Calcd. for $\mathrm{C}_{80} \mathrm{H}_{72} \mathrm{Cl}_{6} \mathrm{~F}_{40} \mathrm{~N}_{2} \mathrm{Pt}_{4}$ ): C, 33.96 (34.14); H, 2.87 (2.58); N, 1.26 (1.00). IR (cm-1): $\mathrm{C}_{6} \mathrm{~F}_{5} \mathrm{X}-$ sensitive mode [44], $801 \mathrm{~s} ; \mathrm{v}(\mathrm{C}-\mathrm{F}), 974 \mathrm{~s}, 960 \mathrm{~s}$; others, $1638 \mathrm{w}, 1607 \mathrm{w}, 1504 \mathrm{vs}$; v(Pt-Cl), $343 \mathrm{w}, 279$ w. ${ }^{19} \mathrm{~F}$ NMR (room temperature), $\mathrm{CD}_{2} \mathrm{Cl}_{2} ; \delta / \mathrm{ppm}:-114.79$ (d, 2Fo, ${ }^{3} J_{\mathrm{Pt}-\mathrm{Fo}}=95 \mathrm{~Hz}$ ), $-118.81\left(\mathrm{~d}, 2 \mathrm{~F}_{0},{ }^{3} J_{\mathrm{Pt}-\mathrm{Fo}}=134 \mathrm{~Hz}\right),-120.32\left(\mathrm{~d}, 2 \mathrm{~F}_{0}\right),-124.94\left(\mathrm{~d}, 2 \mathrm{~F}_{0},{ }^{3} J_{\mathrm{Pt}-\mathrm{Fo}}=96 \mathrm{~Hz}\right),-119.51$ $\left(\mathrm{d}, 4 \mathrm{~F}_{0},{ }^{3} J_{\mathrm{Pt}-\mathrm{Fo}}=483 \mathrm{~Hz}\right),-120.48\left(\mathrm{~d}, 4 \mathrm{~F}_{0},{ }^{3} J_{\mathrm{Pt}-\mathrm{Fo}}=509 \mathrm{~Hz}\right),-157.83\left(\mathrm{~m}, 2 \mathrm{~F}_{p}\right),-158.13(\mathrm{~m}$, $\left.2 \mathrm{~F}_{p}\right),-163.19\left(\mathrm{t}, 1 \mathrm{~F}_{p}\right),-163.25\left(\mathrm{t}, 1 \mathrm{~F}_{p}\right),-164.82\left(\mathrm{t}, 2 \mathrm{~F}_{p}\right),-162.89\left(\mathrm{~m}, 6 \mathrm{~F}_{\mathrm{m}}\right),-163.64\left(\mathrm{~m}, 2 \mathrm{~F}_{m}\right)$, $-165.48\left(\mathrm{~m}, 4 \mathrm{~F}_{m}\right),-166.63\left(\mathrm{~m}, 4 \mathrm{~F}_{m}\right)$.

Preparation of $\left[\mathrm{NBu}_{4}\right]_{2}\left[\left\{\operatorname{Pt}(\mu-\mathrm{OH})\left(\mathrm{C}_{6} \mathrm{~F}_{5}\right)_{2}\right\}_{2}(\mu-\mathrm{Cl})_{4}\left\{\operatorname{Pt}\left(\mathrm{C}_{6} \mathrm{~F}_{5}\right)_{2}\right\}_{2}\right]$ (6). To a solution of $\left[\mathrm{NBu}_{4}\right]_{2}\left[\mathrm{Pt}_{2}(\mu-\mathrm{OH})_{2}\left(\mathrm{C}_{6} \mathrm{~F}_{5}\right)_{4} \mathrm{Cl}_{4}\right](3)$ prepared as described above (approx. $0.12 \mathrm{mmol}$ ) in $\mathrm{CH}_{2} \mathrm{Cl}_{2}(40 \mathrm{~mL})$, cis-[ $\left.\mathrm{Pt}\left(\mathrm{C}_{6} \mathrm{~F}_{5}\right)_{2}(\mathrm{thf})_{2}\right](0.155 \mathrm{~g}, 0.232 \mathrm{mmol})$ was added. After 5 min stirring at room temperature, the resulting red solution was evaporated to dryness. The residue was treated with $n$-hexane $(15 \mathrm{~mL})$ yielding a red solid (6) that was filtered off. Yield: $72 \%$. Anal. Found (Calcd. for $\mathrm{C}_{80} \mathrm{H}_{74} \mathrm{Cl}_{4} \mathrm{~F}_{40} \mathrm{~N}_{2} \mathrm{O}_{2} \mathrm{Pt}_{4}$ ): C, 34.36 (34.59); H, 2.99 (2.68); N, 1.02 (1.01). IR ( $\left.\mathrm{cm}^{-1}\right)$ : $\mathrm{C}_{6} \mathrm{~F}_{5} \mathrm{X}$-sensitive mode [44], $803 \mathrm{~s}$; v(C-F), $972 \mathrm{~s}, 956 \mathrm{~s}$; others, $1639 \mathrm{w}, 1607 \mathrm{w}$, 1502 vs, v(O-H) $3574 \mathrm{~m}$; v(Pt-Cl) 352 w, 282 w. ${ }^{19} \mathrm{~F}$ NMR (room temperature), $\mathrm{CD}_{2} \mathrm{Cl}_{2}$; 


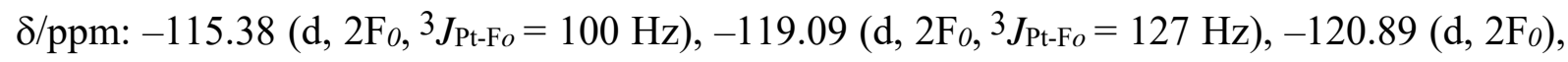
$-125.40\left(\mathrm{~d}, 2 \mathrm{~F}_{0},{ }^{3} J_{\mathrm{Pt}-\mathrm{Fo}}=100 \mathrm{~Hz}\right),-120.34\left(\mathrm{~d}, 4 \mathrm{~F}_{0}\right),-120.70\left(\mathrm{~d}, 4 \mathrm{~F}_{0}\right),-158.26\left(\mathrm{t}, 1 \mathrm{~F}_{\mathrm{p}}\right),-$ $158.66\left(\mathrm{t}, 1 \mathrm{~F}_{p}\right),-159.53\left(\mathrm{~m}, 2 \mathrm{~F}_{p}\right),-164.74\left(\mathrm{t}, 1 \mathrm{~F}_{p}\right),-165.57$ (t, 2F $),-167.09$ (t, $\left.1 \mathrm{~F}_{p}\right),-163.59$ $\left(\mathrm{m}, 4 \mathrm{~F}_{m}\right),-164.55\left(\mathrm{~m}, 2 \mathrm{~F}_{m}\right),-166.12\left(\mathrm{~m}, 2 \mathrm{~F}_{m}\right),-167.09\left(\mathrm{~m}, 8 \mathrm{~F}_{m}\right)$

Preparation of $\left[\mathrm{CoCp}_{2}\right]\left[\mathrm{Pt}_{2}\left(\boldsymbol{\mu}-\mathrm{C}_{8} \mathrm{H}_{6} \mathbf{N}_{4}\right)\left(\mathrm{C}_{6} \mathbf{F}_{5}\right)_{4}\right]$ (7). To an orange solution of $\left[\operatorname{Pt}_{2}(\mu-\right.$ $\left.\left.\mathrm{C}_{8} \mathrm{H}_{6} \mathrm{~N}_{4}\right)\left(\mathrm{C}_{6} \mathrm{~F}_{5}\right)_{4}\right]$ (1) (0.054 g, $\left.0.044 \mathrm{mmol}\right)$ in $10 \mathrm{~mL}$ of thf, $\mathrm{Cp}_{2} \mathrm{Co}$ (purified by sublimation $(0.008 \mathrm{~g}, 0.044 \mathrm{mmol})$ was added. The color of the solution changed immediately to red. After 30 min stirring, the solution was evaporated to dryness and the residue was treated with nhexane. Yield: 69\%. Anal. Found (Calcd. for $\mathrm{C}_{42} \mathrm{H}_{16} \mathrm{~N}_{4} \mathrm{~F}_{20} \mathrm{CoPt}_{2}$ ): C, 35.76 (35.88); H, 1.42 (1.15); N, 4.10 (3.98). IR ( $\left.\mathrm{cm}^{-1}\right): \mathrm{C}_{6} \mathrm{~F}_{5} \mathrm{X}$-sensitive mode [44], $809 \mathrm{~s}, 800 \mathrm{~s} ; \mathrm{v}(\mathrm{C}-\mathrm{F}), 959 \mathrm{~s}$; other, $\mathrm{C}_{8} \mathrm{H}_{6} \mathrm{~N}_{4}: 1580 \mathrm{~m}, 1504 \mathrm{~s}, 1417$ w, 668 w. FAB- $(\mathrm{m} / \mathrm{z}):\left[\mathrm{Pt}_{2}\left(\mathrm{C}_{6} \mathrm{~F}_{5}\right)_{4}\left(\mathrm{C}_{8} \mathrm{H}_{6} \mathrm{~N}_{4}\right)\right]: 1216$

\section{X-ray Structure analysis of $\left[\mathrm{NBu}_{4}\right]_{2}\left[\mathrm{Pt}_{2}\left(\mu-\mathrm{Cl}_{2}\right)_{4} \mathrm{Cl}_{4}\left(\mathrm{C}_{6} \mathrm{~F}_{5}\right)_{4}\right] \quad(2), \quad\left[\mathrm{Pt}_{2}(\mu-\right.$ $\left.\left.\mathrm{C}_{8} \mathrm{H}_{6} \mathrm{~N}_{4}\right) \mathrm{Cl}_{4}\left(\mathrm{C}_{6} \mathrm{~F}_{5}\right)_{4}\right] \cdot 4 \mathrm{Me}_{2} \mathrm{CO} \quad\left(4 \cdot 4 \mathrm{Me}_{2} \mathrm{CO}\right)$ and $\left[\mathrm{NBu}_{4}\right]_{2}\left[\left\{\mathrm{Pt}(\mu-\mathrm{OH})\left(\mathrm{C}_{6} \mathrm{~F}_{5}\right)_{2}\right\}_{2}(\mu-\right.$ $\left.\mathrm{Cl})_{4}\left\{\mathrm{Pt}\left(\mathrm{C}_{6} \mathrm{~F}_{5}\right)_{2}\right\}_{2}\right] \cdot \mathrm{CH}_{2} \mathrm{Cl}_{2}\left(6 \cdot \mathrm{CH}_{2} \mathrm{Cl}_{2}\right)$.}

Relevant crystallographic information for these structures is collected in Supplementary Material (Table 1). Suitable crystals for $\mathrm{X}$ ray diffraction studies were obtained by slow diffusion of $n$-hexane into solutions of the complexes in $\mathrm{Me}_{2} \mathrm{CO}$ ( 2 and 4 ) or $\mathrm{CH}_{2} \mathrm{Cl}_{2}(6)$ at $4{ }^{\circ} \mathrm{C}$.

Crystals of the complexes were mounted at the end of quartz fibers and held in place with epoxy adhesive. Diffraction measurements were made on an Enraf-Nonius CAD-4 diffractometer, using graphite monochromated $\mathrm{Mo}-\mathrm{K}_{\alpha} X$-radiation. Lorentz and polarization corrections were applied.

The structures were solved by direct methods. All non-hydrogen atoms of the complex anion and the cation were assigned anisotropic displacement parameters. The hydrogen atoms of the cation were constrained to idealized geometries and assigned isotropic displacement parameters equal to 1.2 times ( 1.5 times for the methyl carbon atoms) the $U_{\text {iso }}$ values of their respective parent atoms. For $\mathbf{2}$, some very diffuse electron density were found in the final stages of the refinement. After several unsuccessful attempts to model this density as $n$ hexane, one of the crystallization solvents, the SQUEEZE procedure as implemented in the program PLATON [45] was used to deal with this problem. Besides, one of the methyl carbon atoms of the $\mathrm{NBu}_{4}^{+}$cation is disordered over two positions and their occupancies were refined to $0.7 / 0.3$, and the $\mathrm{CH}_{2}-\mathrm{CH}_{3}$ distance were constrained to an idealized value.. For 6 , 
one methyl carbon atom of the $\mathrm{NBu}_{4}$ group was modeled as a pair of atomic sites with occupancy of 0.5 each and the hydrogen atoms of these atoms and the other methyl carbon atoms were omitted. Five atomic sites in an interstitial zone were modeled as a pair of partially occupied, disordered $\mathrm{CH}_{2} \mathrm{Cl}_{2}$ molecules, sharing a common carbon atom. Each of the $\mathrm{CH}_{2} \mathrm{Cl}_{2}$ moieties was assigned 0.25 occupancy; thus, the common $\mathrm{C}$ site had 0.50 occupancy. A common anisotropic displacement parameter was refined for the five atoms of the disordered $\mathrm{CH}_{2} \mathrm{Cl}_{2}$ moieties. Loose restraints to equality were applied to the $\mathrm{C}-\mathrm{Cl}$ distance and $\mathrm{Cl}-\mathrm{C}-\mathrm{Cl}$ angles. Full-matrix least-squares refinement of these models against $\mathrm{F}^{2}$ converged to final residual indices given in Table 1 of the Supplementary Material. The structures were refined using the SHELXL-93 program [46].

Selected crystallographic data, data collection and structure refinement parameters are available in Supporting Information. CCDC 1911936-1911938 contains supplementary crystallographic data on this paper. These data are available, free of charge from The Cambridge Crystallographic Data Centre via www.ccdc.cam.ac.uk/ data_request/cif.

\section{Results and Discussion}

The anionic complex $\left[\mathrm{NBu}_{4}\right]_{2}\left[\mathrm{Pt}_{2}\left(\mu-\mathrm{Cl}_{2}\right)_{2}\left(\mathrm{C}_{6} \mathrm{~F}_{5}\right)_{4}\right]$ was prepared as described elsewhere ${ }^{37}$ and the neutral binuclear platinum(II) complex cis- $\left[\left(\mathrm{C}_{6} \mathrm{~F}_{5}\right)_{2} \mathrm{Pt}(\mu-\right.$ $\left.\left.\mathrm{C}_{8} \mathrm{H}_{6} \mathrm{~N}_{4}\right) \mathrm{Pt}\left(\mathrm{C}_{6} \mathrm{~F}_{5}\right)_{2}\right]$ (1) (See scheme 1) was prepared by reaction of cis- $\left[\mathrm{Pt}\left(\mathrm{C}_{6} \mathrm{~F}_{5}\right)_{2}(\mathrm{thf})_{2}\right]$ and the ligand 2,2'-bipyrimidine, which is able to act as a bridge between the metal centres $[18,47,48]$.

The IR spectrum of complex $\mathbf{1}$ is very informative about the structural disposition of the ligands, The similar intensity of the absorptions at 1586 and $1557 \mathrm{~cm}^{-1}$ indicates the bischelate bridging coordination of the 2,2'-bipyrimidine ligand [48]. Moreover, the presence of only two signals in the ${ }^{1} \mathrm{H}$ NMR spectrum of $\mathbf{1}$ in 2:1 ratio point to a symmetrical arrangement of the N-donor ligand in the complex. In fact, its coordination features are most suitable to synthesize binuclear complexes in which the 2,2'-bipyrimidine ligand bridges two platinum centres with a coplanar disposition of their environments [18,47-49]. The mass spectrum confirms the binuclear nature of complex 1 .

The electronic properties of the 2,2'-bipyridine cause that the complexes that contain it suffer chemical and electrochemical reduction processes [50]. For this reason we have studied the redox behavior of complex 1 by electrochemical methods. Figure 1a shows the cyclic 
voltammogram registered at $200 \mathrm{mVs}^{-1}$ in $\mathrm{MeCN}$ and using a platinum disc as working electrode. There are two reduction waves connecting with two electrochemically reversible reduction processes, the first one corresponding to an electrochemically reversible system $\left(E_{1 / 2(\text { red })}=-0.33 \mathrm{~V}\right)$ and the second one at lower potential $\left(E_{1 / 2(\text { red })}=-1.05 \mathrm{~V}\right)$.

Aiming to know the number of electrons involved in these reductions, we carried out the electrolysis at controlled potential of a solution of complex 1 in $\mathrm{MeCN}$. A potential of $-0.55 \mathrm{~V}$ was applied to $100 \mathrm{~mL}$ of a solution $0.001 \mathrm{M}$ of 1 containing $\mathrm{NBu}_{4} \mathrm{PF}_{6}(0.1 \mathrm{M})$ as supporting electrolyte. Once $9.65 \mathrm{C}$ were transferred to the solution, a strong decrease in the intensity was observed. Moreover, a change in the solution color is observed from orange to brown. The cyclic voltammetry of the resulting solution shows a null intensity of the electrical current at $0.55 \mathrm{~V}$, which confirms that the process corresponding to the wave at $-0.33 \mathrm{~V}$ has been completed after the transference of an equimolecular amount of electrons, thus indicating that the wave observed at $-0.33 \mathrm{~V}$ in the $\mathrm{CV}$ is due to the binuclear anion $\mathbf{1}^{-}$(see Figure 1 in Supplementary Material).

\section{EPR studies of complex cis- $\left[\left(\mathrm{C}_{6} \mathrm{~F}_{5}\right)_{2} \operatorname{Pt}\left(\mu-\mathrm{C}_{8} \mathrm{H}_{6} \mathrm{~N}_{4}\right) \operatorname{Pt}\left(\mathrm{C}_{6} \mathrm{~F}_{5}\right)_{2}\right](1)$.}

The Electron Paramagnetic Resonance (EPR) spectrum of a frozen solution $\left(\mathrm{CH}_{2} \mathrm{Cl}_{2} /\right.$ thf $\left.1: 2\right)$ of a in situ electrochemically generated radical anion of cis- $\left[\left(\mathrm{C}_{6} \mathrm{~F}_{5}\right)_{2} \mathrm{Pt}(\mu-\right.$ $\left.\left.\mathrm{C}_{8} \mathrm{H}_{6} \mathrm{~N}_{4}\right) \mathrm{Pt}\left(\mathrm{C}_{6} \mathrm{~F}_{5}\right)_{2}\right]^{-}\left(\mathbf{1}^{-}\right)$is shown in Figure 2. At first glance it can be associated to a slightly orthorhombic $S=1 / 2$ entity. While the high field feature at $g_{z}=1.934$ does not show any resolved structure, the "perpendicular" low field feature consists of several overlapped lines. A detailed analysis of this structure indicated that the different lines can be grouped in two sets, one of them consists of four lines $11.2 \mathrm{mT}(\mathrm{A}=65(2) \mathrm{MHz})$ apart centered at about $g_{x}=$ 2.029 and the other is formed by five lines $7 \mathrm{mT}(\mathrm{A}=40(2) \mathrm{MHz})$ apart centered at about $g_{y}=$ 2.009. Both sets of lines are indicated in Figure 2 with cross and stars, respectively. The lower trace in the figure shows the second derivative spectrum; a comparison of both traces reinforces the former analysis. Moreover, it seems sensible to consider the cross-marked quartet as a part of a five lines feature, the high field small signal being masked into the start labeled quintet.

The EPR spectra of frozen solution of some similar mononuclear and binuclear platinum radical have been reported [17,50-54]. In all the cases the EPR spectrum is described as due to a $\mathrm{S}=1 / 2$ entity with an slightly orthorhombic $g$-tensor and the structure of 
the features, when resolved, is associated with the hyperfine interaction with the ${ }^{195} \mathrm{Pt}$ nucleus (I $=1 / 2$, natural abundance $33.8 \%$ ). The assignment of this structure to the hyperfine interaction with the Pt nuclei is supported by some DFT calculation [50-53].

Taking into account the similarity of our EPR signal with those previously reported, a similar assignment can be done. In our case we obtain for the spectroscopic relevant parameters the values: $g_{x}=2.029(2), g_{y}=2.009(2), g_{z}=1.934(2), A_{x}=65(2) \mathrm{MHz}, A_{y}=40(2)$ $\mathrm{MHz}$ which are included in Table 1.

In the present case the anisotropy of the $g$-tensor, measured as the difference of the extreme principal $g$-values, $\Delta g$, is lower than that observed in the other $\left\{(\operatorname{bpym})\left[\mathrm{PtR}_{2}\right]_{2}\right\}^{\cdot-}$ radicals while the isotropic contribution, $\mathrm{g}=\left(g_{x}+g_{y}+g_{z}\right) / 3$ is practically independent on the ligand $\mathrm{R}$. The lowering of the g-tensor anisotropy suggests that in our case, $\mathrm{R}=\mathrm{C}_{6} \mathrm{~F}_{5}$, the metal orbital contribution to the unpaired electron orbital is lower than in the other cases.

We have also synthesized the reduced anion as complex $\left[\mathrm{CoCp}_{2}\right]\left[\mathrm{Pt}_{2}(\mu-\right.$ $\left.\left.\mathrm{C}_{8} \mathrm{H}_{6} \mathrm{~N}_{4}\right)\left(\mathrm{C}_{6} \mathrm{~F}_{5}\right)_{4}\right]$ (7) by reaction of the neutral complex 1 with $\mathrm{Cp}_{2} \mathrm{Co}$ freshly sublimated. It has been isolated and its elemental analyses, infrared spectrum and EPR confirm its stoicheiometry and paramagnetic character. (see Experimental)

Synthesis of the platinum (IV) complexes: $\left[\mathrm{NBu}_{4}\right]_{2}\left[\mathrm{Pt}_{2}\left(\mu-\mathrm{X}_{2}\left(\mathrm{C}_{6} \mathrm{~F}_{5}\right)_{4} \mathrm{Cl}_{4}\right][\mathrm{X}=\mathrm{Cl}\right.$ (2), OH (3)] and $\left[\mathrm{Pt}_{2}\left(\mu-\mathrm{C}_{8} \mathrm{H}_{6} \mathrm{~N}_{4}\right)_{2}\left(\mathrm{C}_{6} \mathrm{~F}_{5}\right)_{4} \mathrm{Cl}_{4}\right]$ (4).

The binuclear platinum(IV) complexes $\left[\mathrm{NBu}_{4}\right]_{2}\left[\mathrm{Pt}_{2}(\mu-\mathrm{Cl})_{2}\left(\mathrm{C}_{6} \mathrm{~F}_{5}\right)_{4} \mathrm{Cl}_{4}\right](2)$ and $\left[\mathrm{Pt}_{2}(\mu-\right.$ $\left.\left.\mathrm{C}_{8} \mathrm{H}_{6} \mathrm{~N}_{4}\right)_{2}\left(\mathrm{C}_{6} \mathrm{~F}_{5}\right)_{4} \mathrm{Cl}_{4}\right](4)$ were obtained by addition of a solution of $\mathrm{Cl}_{2}$ in $\mathrm{CCl}_{4}$ in excess to the corresponding $\left[\mathrm{NBu}_{4}\right]_{2}\left[\mathrm{Pt}_{2}(\mu-\mathrm{Cl})_{2}\left(\mathrm{C}_{6} \mathrm{~F}_{5}\right)_{4}\right]$ or $\quad$ cis- $\left[\mathrm{Pt}_{2}\left(\mu-\mathrm{C}_{8} \mathrm{H}_{6} \mathrm{~N}_{4}\right)_{2}\left(\mathrm{C}_{6} \mathrm{~F}_{5}\right)_{4}\right]$ respectively (see Scheme 1-a). These oxidative addition reactions take place under mild conditions and involve the oxidation of both platinum(II) centers in the binuclear $\mathrm{Pt}(\mathrm{II})$ complexes to platinum(IV). The synthesis of complex $\mathbf{3}$ is quite more complicated since the reaction of the hydroxo $\mathrm{Pt}(\mathrm{II})$ derivative $\left[\mathrm{NBu}_{4}\right]_{2}\left[\mathrm{Pt}_{2}(\mu-\mathrm{OH})_{2}\left(\mathrm{C}_{6} \mathrm{~F}_{5}\right)_{4}\right]$ (prepared as described elsewhere [55]), with a solution of $\mathrm{Cl}_{2}$ in $\mathrm{CH}_{2} \mathrm{Cl}_{2}$ under similar conditions to the ones used for the preparation of $\mathbf{2}$ and $\mathbf{4}$ results in a mixture of $\mathrm{Pt}(\mathrm{IV})$ complexes. In our hands and after several attempts the best way to achieve complex $\left[\mathrm{NBu}_{4}\right]_{2}\left[\mathrm{Pt}_{2}(\mu-\mathrm{OH})_{2}\left(\mathrm{C}_{6} \mathrm{~F}_{5}\right)_{4} \mathrm{Cl}_{4}\right](3)$ was by reacting the $\mathrm{Pt}(\mathrm{IV})$ derivative $\left[\mathrm{NBu}_{4}\right]_{2}\left[\mathrm{Pt}_{2}(\mu-\mathrm{Cl})_{2}\left(\mathrm{C}_{6} \mathrm{~F}_{5}\right)_{4} \mathrm{Cl}_{4}\right](2)$ with $\mathrm{NBu} 4 \mathrm{OH}$ in 1:2 molar ratio and the oily residue, which could not be isolated as a solid was spectroscopically 
characterized by IR and NMR.. The substitution reaction of the chlorine ligands takes place selectively on the chlorine bridge ligands instead the terminal ones, probably due to the fact that the Pt-Cl bridging bonds are weaker that the terminal ones. Although complex 3 is not obtained as a solid, the use of the oily sample allows the isolation of the mixed $\mathrm{Pt}(\mathrm{II}) / \mathrm{Pt}(\mathrm{IV})$ complex (6), as we will see latter. The IR spectra (see Experimental) of complexes $\mathbf{2 , 3}$ and $\mathbf{4}$ show the typical absorptions for the $\mathrm{C}_{6} \mathrm{~F}_{5}$ groups at around 970 and $795 \mathrm{~cm}^{-1}$ and the absorptions due to the $v(\mathrm{Pt}-\mathrm{Cl})$ at around 327 and $264 \mathrm{~cm}^{-1}$ for complex 2 , at $337 \mathrm{~cm}^{-1}$ for complex 3 and at $354 \mathrm{~cm}^{-1}$ for complex 4 , It is important to note that the position of the band located around $950 \mathrm{~cm}^{-1}$, assigned to $v(\mathrm{C}-\mathrm{F})$ and related to the formal oxidation state of the central atom is in all cases in accordance with the oxidation states of the Pt centres [44] (see Table 2). For complex 3 the absorption due to the $v(\mathrm{O}-\mathrm{H})$ appears at $3581 \mathrm{~cm}^{-1}$. The ${ }^{1} \mathrm{H}$ NMR spectrum of complex 4 only shows two signals at 9.78 and $8.81 \mathrm{ppm}$ in 2:1 ratio indicating a symmetrical disposition of the metal moieties with respect to the bridging ligand.

\section{Crystal structures of $\left[\mathrm{NBu}_{4}\right]_{2}\left[\mathrm{Pt}_{2}(\mu-\mathrm{Cl})_{2} \mathrm{Cl}_{4}\left(\mathrm{C}_{6} \mathrm{~F}_{5}\right)_{4}\right]^{\cdot} \quad(2), \quad\left[\mathrm{Pt}_{2} \mathrm{Cl}_{4}\left(\mathrm{C}_{6} \mathrm{~F}_{5}\right)_{4}(\mu-\right.$}

\section{$\left.\left.\mathrm{C}_{8} \mathrm{~N}_{4} \mathrm{H}_{6}\right)\right] \cdot 4 \mathrm{Me}_{2} \mathrm{CO}\left(4 \cdot 4 \mathrm{Me}_{2} \mathrm{CO}\right)$.}

Crystallographic data for complexes 2 and $4 \cdot 4 \mathrm{Me}_{2} \mathrm{CO}$ are given in Supplementary Material (Table 1), selected bond distances and angles are also given in Supplementary material (Tables 2 and 3 respectively).

The structure of the complex anion of $2,\left[\mathrm{Pt}_{2}(\mu-\mathrm{Cl})_{2} \mathrm{Cl}_{4}\left(\mathrm{C}_{6} \mathrm{~F}_{5}\right)_{4}\right]^{2-}$, is shown in Figure 3. There is a crystallographic inversion center in the middle of the anion and thus, the position of half of the atoms is generated by this symmetry operator. This anion contains two platinum atoms in formal oxidation state IV with a Pt-Pt distance of 3.664(1) $\AA$ which is similar to that found in the starting platinum(II) complex ${ }^{55}$ and excludes any intermetallic interaction. The platinum(IV) atoms are bridged by two $\mathrm{Cl}$ ligands in a planar arrangement. Moreover, each platinum(IV) center has also coordinated two terminal cis $\mathrm{C}_{6} \mathrm{~F}_{5}$ groups in the same plane and two trans $\mathrm{Cl}$ atoms above and below of the plane, thus resulting an octahedral environment for both metal centers.

The Pt-C distances are equal within the experimental error and similar to the distances found in pentafluorophenylplatinum(II) complexes [56-59]. The $\mathrm{Pt}-\mathrm{Cl}$ terminal distances are slightly shorter than the Pt-Cl bridging ones, and the value of the distances of each type of Pt$\mathrm{Cl}$ bond are also equal within the experimental error. As expected from an octahedral 
geometry the bond angles around each platinum(IV) center are close to $90^{\circ}$ for cis ligands (from $81.6(1)^{\circ}$ to $94.4(2)^{\circ}$ ), and $180^{\circ}$ for trans ligands [from $174.3(2)^{\circ}$ to $178.7(1)^{\circ}$ ].

The comparison of these structural data with the reported in the literature for the starting complex $\left[\mathrm{NBu}_{4}\right]_{2}\left[\mathrm{Pt}_{2}(\mu-\mathrm{Cl})_{2}\left(\mathrm{C}_{6} \mathrm{~F}_{5}\right)_{4}\right][56]$ confirms that the skeleton of the binuclear anion of platinum(II) does not suffer important modifications in the bond distances and angles as a result of the oxidation to platinum(IV).

The structure of the complex $\left[\mathrm{Pt}_{2}\left(\mu-\mathrm{C}_{8} \mathrm{H}_{6} \mathrm{~N}_{4}\right)_{2} \mathrm{Cl}_{4}\left(\mathrm{C}_{6} \mathrm{~F}_{5}\right)_{4}\right]$ (4) is shown in Figure 4. As for complex 2, half of the positions of the atoms of the molecule are generated by a crystallographic inversion center. This molecule contains two platinum atoms in formal oxidation state IV bridged by a neutral tetradentate $\mathrm{N}$-ligand $\left(\mathrm{C}_{8} \mathrm{H}_{6} \mathrm{~N}_{4}\right)$ coordinated to each platinum atom through two nitrogen atoms in a chelating form. Moreover, each platinum(IV) center is bonded to two terminal cis $\mathrm{C}_{6} \mathrm{~F}_{5}$ groups located in the same plane as the neutral ligand. The octahedral environment of the platinum atoms is completed by two trans $\mathrm{Cl}$ atoms. There are not significant changes in the structure of the coordinated 2,2'-bipyrimidine with respect to the free ligand [60].

The $\mathrm{Pt}-\mathrm{C}$ and the $\mathrm{Pt}-\mathrm{Cl}$ distances are similar to the corresponding ones in 2 . The $\mathrm{Pt}-\mathrm{N}$ distances are in the range found in other platinum(II) or platinum(IV) complexes containing nitrogen donor ligands $[2,3,36]$. The $\mathrm{N}(1)-\mathrm{Pt}-\mathrm{N}(2)$ angle is quite narrow $\left(77.9(2)^{\circ}\right)$ due to the chelating nature of the bridging ligand, while the other angles around the platinum atom are in the range from $82.6(2)^{\circ}$ to $97.3(3)^{\circ}$ for cis ligands, and from $172.3(1)^{\circ}$ to $175.0(3)^{\circ}$ for trans ligands. The Pt-Pt distance is 5.698(1) $\AA$, within the range of other complexes with this bridging ligand [18].

Synthesis of mixed valence platinum(II)-platinum(IV) complexes: $\left[\mathrm{NBu}_{4}\right]_{2}[\{\operatorname{Pt}(\mu-$ $\left.\left.\mathrm{X})\left(\mathrm{C}_{6} \mathrm{~F}_{5}\right)_{2}\right\}_{2}(\mu-\mathrm{Cl})_{4}\left\{\mathrm{Pt}\left(\mathrm{C}_{6} \mathrm{~F}_{5}\right)_{2}\right\}_{2}\right][\mathrm{X}=\mathrm{Cl}(5), \mathrm{OH}(6)]$.

The terminal chloro ligands of the binuclear platinum(IV) complexes $\mathbf{2}, \mathbf{3}$ and $\mathbf{4}$ are suitable for acting as a bridging group between the platinum(IV) atom and other platinum centers, thus allowing the synthesis of derivatives of higher nuclearity. On the other hand cis$\left[\mathrm{Pt}\left(\mathrm{C}_{6} \mathrm{~F}_{5}\right)_{2}(\mathrm{thf})_{2}\right]$ has proved to be an excellent synthon for the preparation of polynuclear complexes due to the lability of the thf ligands bonded to the metal center [61-64] generating the acid fragment "cis-Pt $\left(\mathrm{C}_{6} \mathrm{~F}_{5}\right)_{2}$ ", which easily incorporates to other Pt complexes. Bearing this in mind, we carried out the reactions of the $\mathrm{Pt}(\mathrm{IV})$ complexes 2 and $\mathbf{3}$ with the $\mathrm{Pt}(\mathrm{II})$ 
synthon cis- $\left[\mathrm{Pt}\left(\mathrm{C}_{6} \mathrm{~F}_{5}\right)_{2}(\text { thf })_{2}\right]$ in 1:2 molar ratio aiming to prepare Pt complexes of higher nuclearity and in mixed oxidation state $[\mathrm{Pt}(\mathrm{IV}) / \mathrm{Pt}(\mathrm{II})]$. This synthetic approach is different to those described in the literature for the preparation of $\mathrm{Pt}(\mathrm{II})-\mathrm{Pt}(\mathrm{IV})$ mixed-valence complexes [15,21-30]. In the reactions of complexes 2 and 3 with cis-[ $\left.\operatorname{Pt}\left(\mathrm{C}_{6} \mathrm{~F}_{5}\right)_{2}(\text { thf })_{2}\right]$, a dramatic change in the colour of the solution is produced due to charge-transfer absorption band indicating the formation of a chloride-bridged mixed valence complexes [21,65]. From these solutions, the tetranuclear $\mathrm{Pt}(\mathrm{IV})-\mathrm{X}-\mathrm{Pt}(\mathrm{II}) \quad$ complexes. $\left[\mathrm{NBu}_{4}\right]_{2}\left[\left\{\mathrm{Pt}(\mu-\mathrm{X})\left(\mathrm{C}_{6} \mathrm{~F}_{5}\right)_{2}\right\}_{2}(\mu-\right.$ $\left.\mathrm{Cl})_{4}\left\{\mathrm{Pt}\left(\mathrm{C}_{6} \mathrm{~F}_{5}\right)_{2}\right\}_{2}\right][\mathrm{X}=\mathrm{Cl}(\mathbf{5}), \mathrm{OH}(\mathbf{6})]$ are obtained as red solids. The IR spectra of these complexes show two $v(\mathrm{C}-\mathrm{F})$ bands due to the presence of platinum centers in two different oxidation states (see Table 2). In addition, the IR spectra show the absorptions due to the $v(\mathrm{Pt}-\mathrm{Cl})$ at 343 and $279 \mathrm{~cm}^{-1}$ for 7 and at 325 and $282 \mathrm{~cm}^{-1}$ for $\mathbf{6}$, in addition the absorption due to the $v(\mathrm{O}-\mathrm{H})$ at $3574 \mathrm{~cm}^{-1}$ for 6 .

The ${ }^{19} \mathrm{~F}$ NMR spectra confirm the presence of pentafluorophenyl groups bonded to platinum atoms in different oxidation states. that can be easily distinguish, when the platinum satellites are not overlapped with other signals, because the ortho-fluorine atoms corresponding to $\mathrm{C}_{6} \mathrm{~F}_{5}$ groups bonded to $\mathrm{Pt}(\mathrm{IV})$ atoms present smaller coupling constant (100$130 \mathrm{~Hz}$ ) than groups bonded to $\mathrm{Pt}(\mathrm{II})$ (around $500 \mathrm{~Hz}$ ).

It is interesting to mention that, under similar conditions to those used in the synthesis of complexes 5 and $\mathbf{6}$, there is no reaction between $\left[\mathrm{Pt}_{2}\left(\mu-\mathrm{C}_{8} \mathrm{H}_{6} \mathrm{~N}_{4}\right)_{2} \mathrm{Cl}_{4}\left(\mathrm{C}_{6} \mathrm{~F}_{5}\right)_{4}\right]$ (4) and cis$\left[\mathrm{Pt}\left(\mathrm{C}_{6} \mathrm{~F}_{5}\right)_{2}(\mathrm{thf})_{2}\right]$. This could be the result of the longer separation between the $\mathrm{Pt}(\mathrm{IV})$ centres in complex 4 created by the 2,2'-bipyrimidine ligand and in consequence between the chloride ligands of both metal atoms that should act as a bridge.

Crystal structure of $\left[\mathrm{NBu}_{4}\right]_{2}\left[\left\{\operatorname{Pt}(\mu-\mathrm{OH})\left(\mathrm{C}_{6} \mathrm{~F}_{5}\right)_{2}\right\}_{2}(\mu-\mathrm{Cl})_{4}\left\{\operatorname{Pt}\left(\mathrm{C}_{6} \mathrm{~F}_{5}\right)_{2}\right\}_{2}\right] \cdot \mathrm{CH}_{2} \mathrm{Cl}_{2}$ $\left(6 \cdot \mathrm{CH}_{2} \mathrm{Cl}_{2}\right)$

Crystallographic data and selected bond distances and angles for complex $\mathbf{6} \cdot \mathrm{CH}_{2} \mathrm{Cl}_{2}$ are given in Supplementary material (Tables 1 and 4 respectively). The structure of the complex anion is shown in Fig. 5a and the central core is shown in Figure 5b. The anion is located around an inversion center in $P 21 / n$. space group. The core of this anion presents a chair like disposition and comprises four platinum atoms, two of them in formal oxidation state (II) and square planar coordination environment and the other two in formal oxidation state (IV) and 
octahedral environments. The platinum(IV) centres are bridged by two hydroxo groups while each platinum(II) centre is connected with the two platinum(IV) atoms by bridging chloride ligands. The $\mathrm{Pt}(\mathrm{II})-\mathrm{Pt}(\mathrm{IV})$ and $\mathrm{Pt}(\mathrm{IV})-\mathrm{Pt}(\mathrm{IV})$ distances are 3.848(1) $\AA$ and 3.289(1) $\AA$ respectively, excluding the existence of any metal-metal bonding.

The two $\mathrm{Pt}(\mathrm{IV})$ moieties are formed by two $\mu-\mathrm{OH}$ ligands in cis positions, two terminal cis $\mathrm{C}_{6} \mathrm{~F}_{5}$ groups and two trans- $\mu-\mathrm{Cl}$ atoms in apical positions thus completing an octahedral environment for both metal centers. The bond angles around each $\operatorname{Pt}(\mathrm{IV})$ center range from $76.5(4)^{\circ}$ to $97.6(6)^{\circ}$ for cis ligands, the smallest value corresponding to $\mathrm{O}-\mathrm{Pt}-\mathrm{O}$, and from $169.7(6)^{\circ}$ to $177.1(2)^{\circ}$ for trans ligands. Each $\mathrm{Pt}(\mathrm{II})$ atom has two terminal cis $\mathrm{C}_{6} \mathrm{~F}_{5}$ groups and two cis $\mathrm{Cl}$ atoms which form a quasi perfect square planar environment [angles for cis ligands range from $88.1(7)^{\circ}$ to $\left.93.4(5)^{\circ}\right]$.

Each $\mathrm{Pt}(\mathrm{II})$ fragment is connected to each one of the two $\mathrm{Pt}(\mathrm{IV})$ centres through one $\mathrm{Cl}$ atom acting as bridging ligand and the $\mathrm{Pt}^{\mathrm{IV}}-\mathrm{Cl}$ distances are longer than the $\mathrm{Pt}^{\mathrm{II}}-\mathrm{Cl}$ ones (see Supplementary Material, Table 4). These $\mathrm{Pt}-\mathrm{Cl}$ bridging distances [range from 2.292(6) to 2.406(4) $\AA$ ] are similar to those found in other $\mu$-chlorideplatinum(IV)platinum(II) complexes [42]. The values of the $\mathrm{Pt}{ }^{\mathrm{IL}}-\mathrm{Cl}-\mathrm{Pt}^{\mathrm{IV}}$ angles [109.3(2) and 108.3(2) ${ }^{\circ}$ are greater than those found in complex $\left[\mathrm{NEt}_{4}\right]_{2}\left[\mathrm{Pt}_{2}(\mathrm{NO})_{2} \mathrm{Cl}_{6}\right][24]$ which contains two platinum atoms in different oxidation states (IV,II) and where the two metal centers are bridged by a chlorine atom and a NO ligand. The steric requirements of the $\mathrm{C}_{6} \mathrm{~F}_{5}$ groups could be responsible of this broader $\mathrm{Pt}(\mathrm{II})-\mathrm{Cl}-\mathrm{Pt}(\mathrm{IV})$ angle. The $\mathrm{Pt}-\mathrm{C}$ distances are equal within the experimental error disregarding of the platinum formal oxidation state, and similar to other complexes containing the $\operatorname{Pt}\left(\mathrm{C}_{6} \mathrm{~F}_{5}\right)_{2}$ fragment [56-59].

The two square planar environments of the Pt(II) atoms lie parallel to each other due to the symmetry of the anion and these planes form a dihedral angle of $26.6^{\circ}$ with the plane containing both Pt(IV) and the oxygen atoms. The dihedral angle between the square planes of $\mathrm{Pt}(\mathrm{II})$ and the plane containing the platinum(IV) atoms and chlorine atoms is $119.9^{\circ}$. The structure of complex 6 resemble the pentanuclear complex $\left[\mathrm{NBu}_{4}\right]_{2}\left[\left\{\mathrm{Pt}^{\mathrm{IV}}{ }_{2}(\mu-\mathrm{Cl})_{2}(\mathrm{Cl})_{8}\right\}\right\}_{2}(\mu-$ $\left.\mathrm{Pt}^{\mathrm{II}}\right)$ ] [42], where two dinuclear platinum (IV) units are bridged by a platinum(II) centre which is bonded to one of the axial chlorine ligand of each platinum(IV).

The comparison of these structural data with the ones reported for complex $\left[\mathrm{NBu}_{4}\right]_{2}\left[\mathrm{Pt}_{2}(\mu-\mathrm{OH})_{2}\left(\mathrm{C}_{6} \mathrm{~F}_{5}\right)_{4}\right][55]$ confirms that the skeleton of the binuclear complex anion does not suffer any important modifications in the bond distances and angles as consequence 
of the oxidation reaction to platinum (IV) and the incorporation of the two "cis- $\mathrm{Pt}^{\mathrm{II}}\left(\mathrm{C}_{6} \mathrm{~F}_{5}\right)_{2}$ " fragments to the $\mathrm{Pt}(\mathrm{IV})$ substrates. Additionally, the X-ray structure reveals that the described reactions does not produce any intramolecular reorganization of ligands nor a modification on the formal oxidation states of the Pt centres.

Aknowledgements. We thank Pablo Alonso for helpful discussions and suggestions on the EPR results. This work has been suported by the Spanish MINECO/FEDER (Project CTQ2015-67461-P and MAT2015-68200-C2-1-P) and the Gobierno de Aragón and Fondo Social Europeo (Grupos de referencia E17_17R: Química Inorgánica y de los Compuestos Organometálicos and M4, E11_17R).

Supporting Information Available: Supplementary data related to this article can be found at... 


\section{References}

[1] L.M. Rendina, R.J. Puddephatt, Chemical Reviews 6 (1997) 1735-1754.

[2] J. Forniés, C. Fortuño, M.A. Gomez, B. Menjón, Organometallics 12 (1993) 43684375.

[3] J.M. Casas, A. Martín, J. Oliva, M. Tomás, Inorg. Chim. Acta 229 (1995) 291-298.

[4] W. Oberhauser, C. Bachmann, T. Stampfl, P. Brüggeller, Inorg. Chim. Acta 256 (1997) 223-234.

[5] J. Vicente, A. Arcas, M.D. Gálvez-López, P.G. Jones, D. Bautista, Organometallics 28 (2009) 3501-3517.

[6] R. van Asselt, E. Rijnberg, C. J. Elsevier, Organometallics 13 (1994) 706-720.

[7] S. Achar, R.J. Puddephat, Organometallics 14 (1995) 1681-1687.

[8] D.B. Dell'Amico, F. Calderazzo, F. Marchetti, S. Ramello, S. Samaritani, Inorg. Chem. 47 (2008) 1237-1242.

[9] E.M. Prokopchuk, R.J. Puddephatt, Organometallics 22 (2003) 563-566.

[10] B. Menjón, S. Martínez-Salvador, M.A. Gómez-Saso, J. Forniés, L.R. Falvello, A. Martín, A. Tsipis, Chem. Eur. J. 15 (2009) 6371-6382.

[11] N; Duran, W. Clegg, K. A; Fraser, P. Gonzalez-Duarte, Inorganica Chimica Acta 300302 (2000) 790-799.

[12] M.S. Safa, M.C. Jennings, R.J. Puddephat, Chem. Commun. (2009) 1487-1489.

[13] Monaghan, P.K.; Puddephat, R.J. Organometallics 4 (1985) 1406-1412.

[14] R.H.W. Au, C.S.A. Fraser, D.J. Eisler, M.C. Jennings, R.J. Puddephat, Organometallics 28 (2009) 1719-1729.

[15] P.M. Cook, L.F. Dahl, D.W. Dickerhoof, J. Am. Chem. Soc. 94 (1972) 5511-5513.

[16] T.S. Khodashova, V.S. Sergienko, A.N. Stetsenko, M.A. Porai-Koshits, L.A. Butman, Zh. Strukt. Khim. 15 (1974) 471-477.

[17] C.M. Bates, P.K. Khanna, C.P. Morley, M. Di Vaira, Chem. Commun. (1997) 913914.

[18] A. Klein, W. Kaim, F. M. Hornung, J. Fiedler, S. Zalis, Inorganica Chimica Acta 264 (1997) 269-278.

[19] Kelly, M. E.; Gómez-Ruiz, S.; Kluge, R.; Merzweiler, K.; Steinborn, D.; Wagner, C.; Schmidt, H. Inorg. Chim. Acta, 362, (2009) 1323-1332.

[20] D.B. Dell'Amico, F. Calderazzo, F. Marchetti, S. Ramello, S. Samaritani, Inorg. Chem. 47,(2008) 1237-1242.

[21] R.J.H. Clark, Chem. Soc. Rev. 19 (1990) 107-131.

[22] M.B. Robin, P. Day, Adv. Inorg. Chem. Radiochem. 10 (1967) 247-422.

[23] L.V. Interrante, K.W. Browall, F.P. Bundy, Inorg. Chem. 13 (1974) 1158-1162.

[24] J.M. Epstein, A.H. White, S.B. Wild, A.C. Willis, J. Chem. Soc., Dalton Trans. (1974) 436-439. 
[25] E.W. Abel, N.A. Cooley, K. Kite, K.G. Orrell, V. Sik, M.B. Hursthouse, H.M. Dawes, Polyhedron 6, (1987) 1261.

[26] H. Hillebrecht, G. Thiele, P.; Hollmann, W.Z. Preetz, Naturforsch., Teil B 47 (1992) 1099-1104.

[27] G. Thiele, H.W.; Rotter, W. Bachle, Anorg. Allg. Chem. 620, 1994, 1271.

[28] S. Shimada, M. Tanaka, K. Honda, J. Am. Chem. Soc. 117 (1995) 8289.

[29] S.S. Ling, R.J; Puddephatt, L. Manojlovic-Muir, K.W. Muir, J. Organomet. Chem. 255 (1983) C11.

[30] S.S. Ling, N.C. Payne, R.J. Puddephatt, Organometallics 4 (1985) 1546.

[31] N. Matsushita, Acta Crystallographica Section E 59 (2003) M26-M28.

[32] T.N. Fedotova, L.K. Minacheva, G.N. Kuznetsova, Russian Journal of Inorganic Chemistry 48, (2003) 1163-1167.

[33] K. Noro, Y. Ozawa, M. Taguchi, A. Yagasaki, Chem. Commun. (2002) 1770-1771.

[34] Kobayashi, A.; Kitagawa, H. J. Am. Chem. Soc. 128 (2006) 12066.

[35] M. Yamashita, H. Aso, S. Matsunaga, K. Takizawa, K. Nakata, C. Kachi-Terajima, F. Iwahori, T. Ishii, H. Miyasaka, K. Sugiura, T. Kawashima, K. Takai, N. Kuroda, M. Shiro, H. Kishida, H. Okamoto, H. Takahashi, H. Tanaka, K. Marumoto, S. Kuroda, Chemistry Letters 32 (2003) 278-279.

[36] S. Achar, J.J. Vittal, R.J. Puddephat, Organometallics 15 (1996) 43.

[37] J.D. Scott, M. Crespo, C.M. Anderson, R.J. Puddephatt, Organometallics 6 (1987) 1772.

[38] A. Arias, J. Forniés, C. Fortuño, A. Martín, Inorg. Chem. 51 (2012) 12682-12696.

[39] A. Arias, J. Forniés, C. Fortuño, A. Martín, P. Mastrorilli, S; Todisco, M.; Latronico, V. Gallo, Inorg. Chem. 52 (2013) 5493-5506.

[40] I. Ara, M.A. García-Monforte, R. González, L.R. Falvello, M. Tomás, Chem. Commun. 53 (2017) 13121-13124.

[41] M.A. Gomez-Saso, Ph. D. Thesis 1994, Universidad de Zaragoza.

[42] D.B. Dell' Amico, L. Labella, F. Marchetti, S. Ramello, S. Samaritani, Inorganic Chemistry Communications 95 (2018) 167-169.

[43] R. Usón, J. Forniés, M. Tomás, R. Fandos, J. Organomet. Chem. 263 (1984) 253-260.

[44] R. Usón, J. Forniés, Adv. Organomet. Chem. 28 (1988) 188 and references given therein.

[45] A.L.Spek, Acta Cryst. D65 (2009) 148-155.

[46] G.M. Sheldrick, Acta Cryst. C71 (2015) 3-8.

[47] F. Baumann, W. Kaim,; M. García Posse, N.E. Katz, Inorg. Chem. 37 (1998) 658-660.

[48] G. De Munno, M. Julve, F. Lloret, A. Derory, J. Chem. Soc., Dalton Trans. (1993) 1179-1184.

[49] W. Kaim, S. Kohlmann, Inorg. Chem. 26 (1987) 68-77.

[50] W. Kaim, A. Dogan, M. Wanner, A. Klein, I. Tiritiris, T. Schleid, D.J. Stufkens, T.L. Snoeck, E.J.L. Mclnnes, J. Fiedler, S. Zalis, Inorg. Chem. 41 (2002) 4139-4148. 
[51] D. Collison, F.E. Mabbs, E.J.L. McInnes, K.J. Taylor, A.L. Welch, L.J. Yellowlees, J. Chem. Soc., Dalton Trans. (1996) 329-334.

[52] E. J. L.; McInnes, R. D.; Farley, S. A.; Macgregor, K. J.; Taylor, L. J.; Yellowlees, C. J. Rowland, Chem. Soc, Faraday Trans. 94 (1998) 2985-2991.

[53] A. Klein, E.J.L. McInnes, T. Scheiring, S. Záliš, J. Chem. Soc, Faraday Trans. 94 (1998) 2979-2984.

[54] A. Klein, W. Kaim, Organometallics 14 (1995) 1176-1186.

[55] G. Lopez, J. Ruiz, G. García, C. Vicente, J.M. Marti, J.A. Hermoso, A. Vegas, M. Martínez-Ripoll, J. Chem. Soc., Dalton Trans. 1992, 53-58.

[56] R. Usón, J. Forniés, M. Tomás, J.M. Casas, L.R. Falvello, R. Llusar, Organomet. 7 (1988) 2279-2285.

[57] R. Usón, J. Forniés, M. Tomás, J. M. Casas, R. Navarro, J. Chem. Soc., Dalton Trans. (1989) 169-172.

[58] J.M. Casas, J. Forniés, A. Martín, B. Menjón, Organometallics 12 (1993) 4376-4380.

[59] I. Ara, J.M. Casas, J. Forniés, A. Rueda, Inorg. Chem. 35 (1996) 7345-7349.

[60] L. Fernholt, C. Romming, S. Samdal, Acta Chem. Scand. A. 35 (1987) 707-715.

[61] R. Usón, J. Forniés, M. Tomás, J.M. Casas, F.A. Cotton, L.R. Falvello, Inorg. Chem. 1987, 26, 3482-3486.

[62] R. Usón, J. Forniés, M. Tomás, B. Menjón, Organometallics 4 (1985) 1912-1914.

[63] R. Usón, J. Forniés, M. Tomás, B. Menjón, Organometallics 7 (1988) 1318-1323.

[64] L.R. Falvello, J. Forniés, R. Navarro, V. Sicilia, M. Tomás, Angew. Chem., Int. Ed. Engl. 29 (1990) 891-893.

[65] N. Kimizuka, N. Oda, T. Kunitake, Inorg. Chem. 39 (2000) 2684-2689. 
Table 1. v(C-F) of several pentafluorophenyl complexes in oxidation state (O.S.) II and IV.

\begin{tabular}{|l|l|l|}
\hline COMPOUND & Pt O.S. & $v(\mathrm{C}-\mathrm{F}) \mathrm{cm}^{-1}$ \\
\hline cis- $\left[\left(\mathrm{C}_{6} \mathrm{~F}_{5}\right)_{2} \mathrm{Pt}\left(\mu-\mathrm{C}_{8} \mathrm{H}_{6} \mathrm{~N}_{4}\right) \mathrm{Pt}\left(\mathrm{C}_{6} \mathrm{~F}_{5}\right)_{2}\right](\mathbf{1})$ & & \\
\hline$\left[\mathrm{CoCp}_{2}\right]\left[\mathrm{Pt}_{2}\left(\mu-\mathrm{C}_{8} \mathrm{H}_{6} \mathrm{~N}_{4}\right)\left(\mathrm{C}_{6} \mathrm{~F}_{5}\right)_{4}\right](\mathbf{7})$. & II & 956 \\
\hline$\left[\mathrm{Pt}_{2}\left(\mu-\mathrm{C}_{8} \mathrm{H}_{6} \mathrm{~N}_{4}\right) \mathrm{Cl}_{4}\left(\mathrm{C}_{6} \mathrm{~F}_{5}\right)_{4}\right](\mathbf{4})$ & II & 966 \\
\hline & IV & 974 \\
\hline$\left[\mathrm{NBu}_{4}\right]_{2}\left[\mathrm{Pt}_{2}(\mu-\mathrm{Cl})_{2}\left(\mathrm{C}_{6} \mathrm{~F}_{5}\right)_{4}\right]$ & & \\
\hline$\left[\mathrm{NBu}_{4}\right]_{2}\left[\mathrm{Pt}_{2}(\mu-\mathrm{Cl})_{2}\left(\mathrm{C}_{6} \mathrm{~F}_{5}\right)_{4} \mathrm{Cl}_{4}\right]$ & II & \\
\hline$\left[\mathrm{NBu}_{4}\right]_{2}\left[\left\{\mathrm{Pt}(\mu-\mathrm{Cl})\left(\mathrm{C}_{6} \mathrm{~F}_{5}\right)_{2}\right\}_{2}(\mu-\mathrm{Cl})_{4}\left\{\mathrm{Pt}_{\left.\left.\left(\mathrm{C}_{6} \mathrm{~F}_{5}\right)_{2}\right\}_{2}\right](\mathbf{5})}\right.\right.$ & IV & IV, II \\
\hline & & 966 \\
\hline$\left[\mathrm{NBu}_{4}\right]_{2}\left[\mathrm{Pt} 2(\mu-\mathrm{OH})_{2}\left(\mathrm{C}_{6} \mathrm{~F}_{5}\right)_{4}\right]$ & II & \\
\hline$\left[\mathrm{NBu}_{4}\right]_{2}\left[\mathrm{Pt} 2(\mu-\mathrm{OH})_{2}\left(\mathrm{C}_{6} \mathrm{~F}_{5}\right)_{4} \mathrm{Cl}_{4}\right](\mathbf{3})$ & IV & 953 \\
\hline$\left[\mathrm{NBu}_{4}\right]_{2}\left[\left\{\mathrm{Pt}(\mu-\mathrm{OH})\left(\mathrm{C}_{6} \mathrm{~F}_{5}\right)_{2}\right\}_{2}(\mu-\mathrm{Cl})_{4}\left\{\mathrm{Pt}_{\left.\left.\left(\mathrm{C}_{6} \mathrm{~F}_{5}\right)_{2}\right\}_{2}\right](\mathbf{6})}\right.\right.$ & IV, II & 965 \\
\hline
\end{tabular}


Table 2. Spin-Hamiltonian parameters of some $\left\{(\mathrm{bpym})\left[\mathrm{PtR}_{2}\right]_{2}\right\}^{-}$radicals.

\begin{tabular}{|c|c|c|c|c|c|c|c|c|c|}
\hline & $g_{1}$ & $g_{2}$ & $g_{3}$ & $g$ & $\Delta g$ & $A_{1}(\mathrm{MHz})$ & $A_{2}(\mathrm{MHz})$ & $A_{3}(\mathrm{MHz})$ & ref. \\
\hline$\left\{(\text { bpym })\left[\mathrm{PtMe}_{2}\right]_{2}\right\}^{\cdot-}$ & 2.055 & 2.011 & 1.895 & 1.987 & 0.160 & 43 & 51 & (53) & 53 \\
\hline$\left\{(\mathrm{bpym})\left[\mathrm{PtCl}_{2}\right]_{2}\right\} \cdot-$ & 2.049 & 2.008 & 1.902 & 1.986 & 0.147 & 111 & 143 & $<80$ & 50 \\
\hline$\left\{(\text { bpym })\left[\text { PtMes }_{2}\right]_{2}\right\}^{\cdot-}$ & 2.0435 & 2.0091 & 1.916 & 1.990 & 0.128 & - & 45 & - & 18 \\
\hline$\left\{(\text { bpym })\left[\text { PtMes }_{2}\right]_{2}\right\}^{\cdot-}$ & 2.040 & 2.008 & 1.917 & 1.988 & 0.123 & 49 & 53 & (54) & 53 \\
\hline$\left\{(\text { bpym })\left[\operatorname{Pt}\left(\mathrm{C}_{6} \mathrm{~F}_{5}\right)_{2}\right]_{2}\right\}^{--}$ & 2.029 & 2.009 & 1.934 & 1.991 & 0.095 & 65 & 40 & - & $*$ \\
\hline
\end{tabular}

*included in this article. 


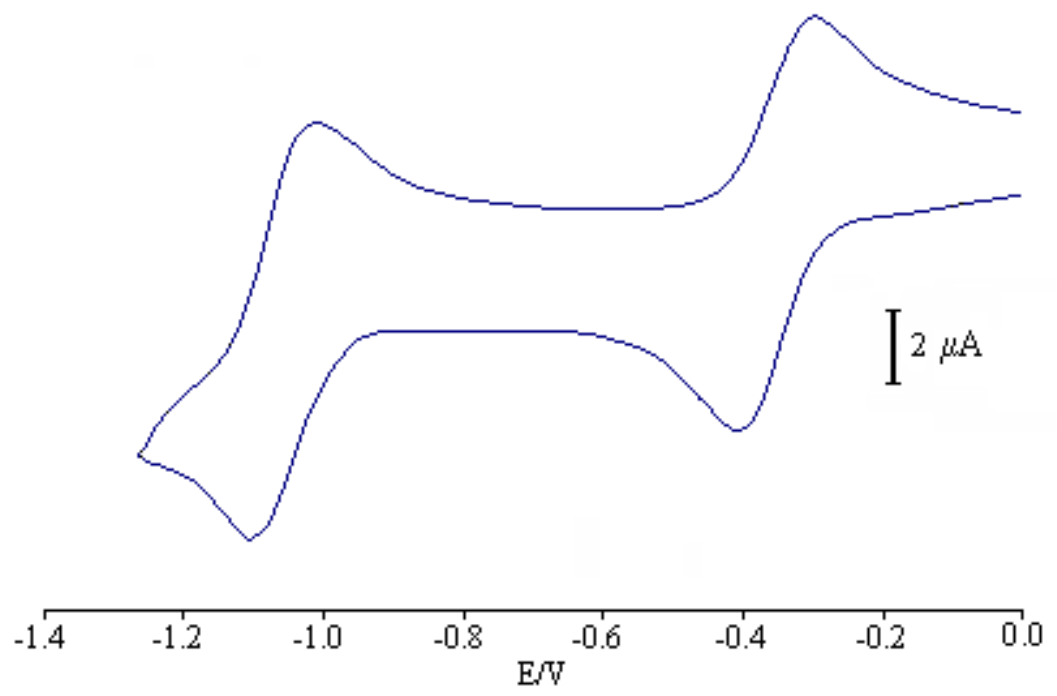

Fig. 1 a

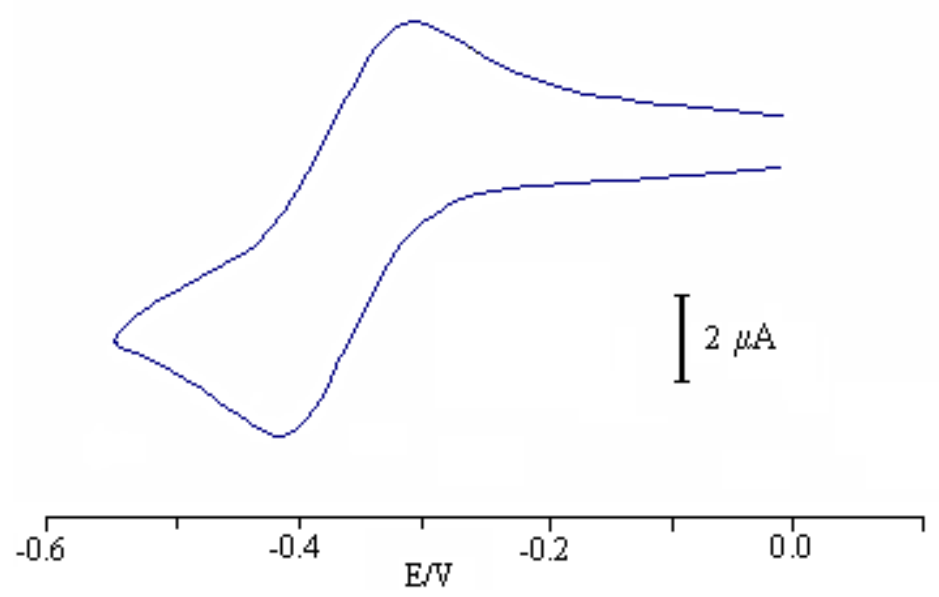

Fig. $1 \mathrm{~b}$

Figure 1, a) Cyclic voltammogram of cis- $\left[\left(\mathrm{C}_{6} \mathrm{~F}_{5}\right)_{2} \mathrm{Pt}\left(\mu-\mathrm{C}_{8} \mathrm{H}_{6} \mathrm{~N}_{4}\right) \mathrm{Pt}\left(\mathrm{C}_{6} \mathrm{~F}_{5}\right)_{2}\right]$ (1) in $\mathrm{MeCN}$. b) A detail of first wave of the cyclic voltammogram. 


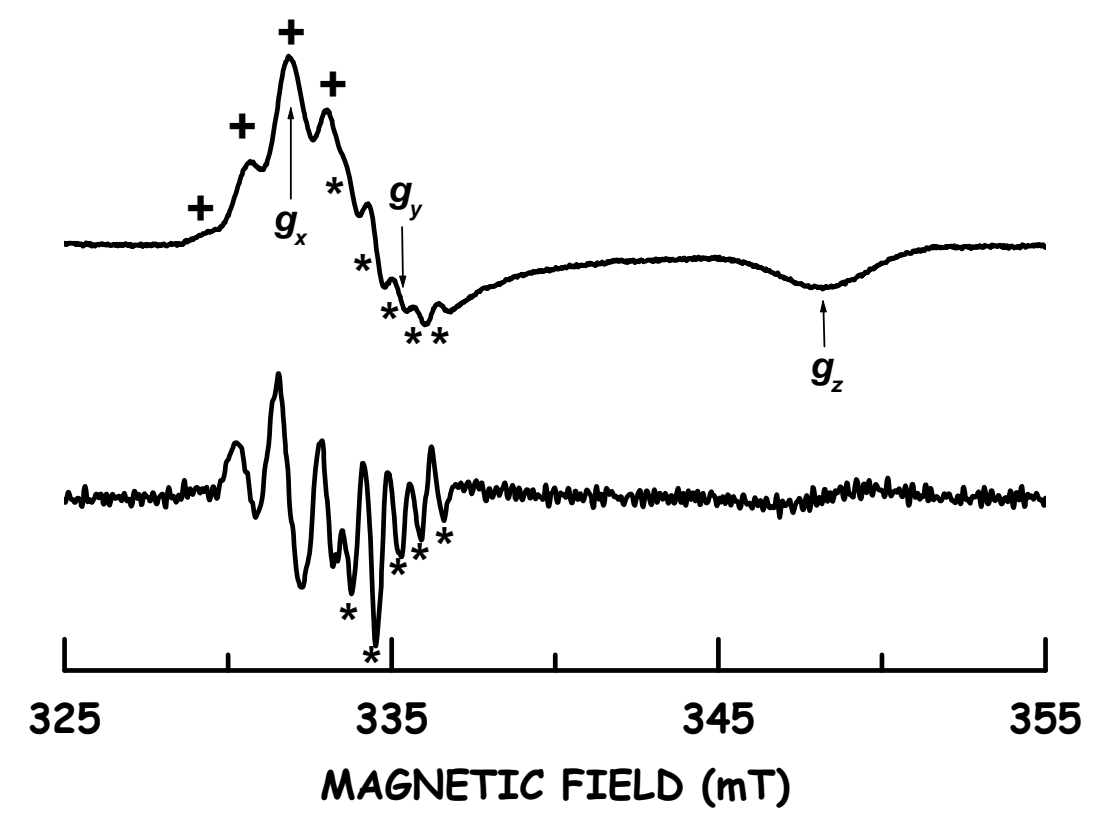

Figure 2. Electron Paramagnetic Resonance spectrum (upper trace) and the second derivative (lower trace) of a frozen solution $\left(\mathrm{CH}_{2} \mathrm{Cl}_{2} /\right.$ thf $\left.1: 2\right)$ of a in situ generated radical anion $\mathbf{1}^{-}$ 


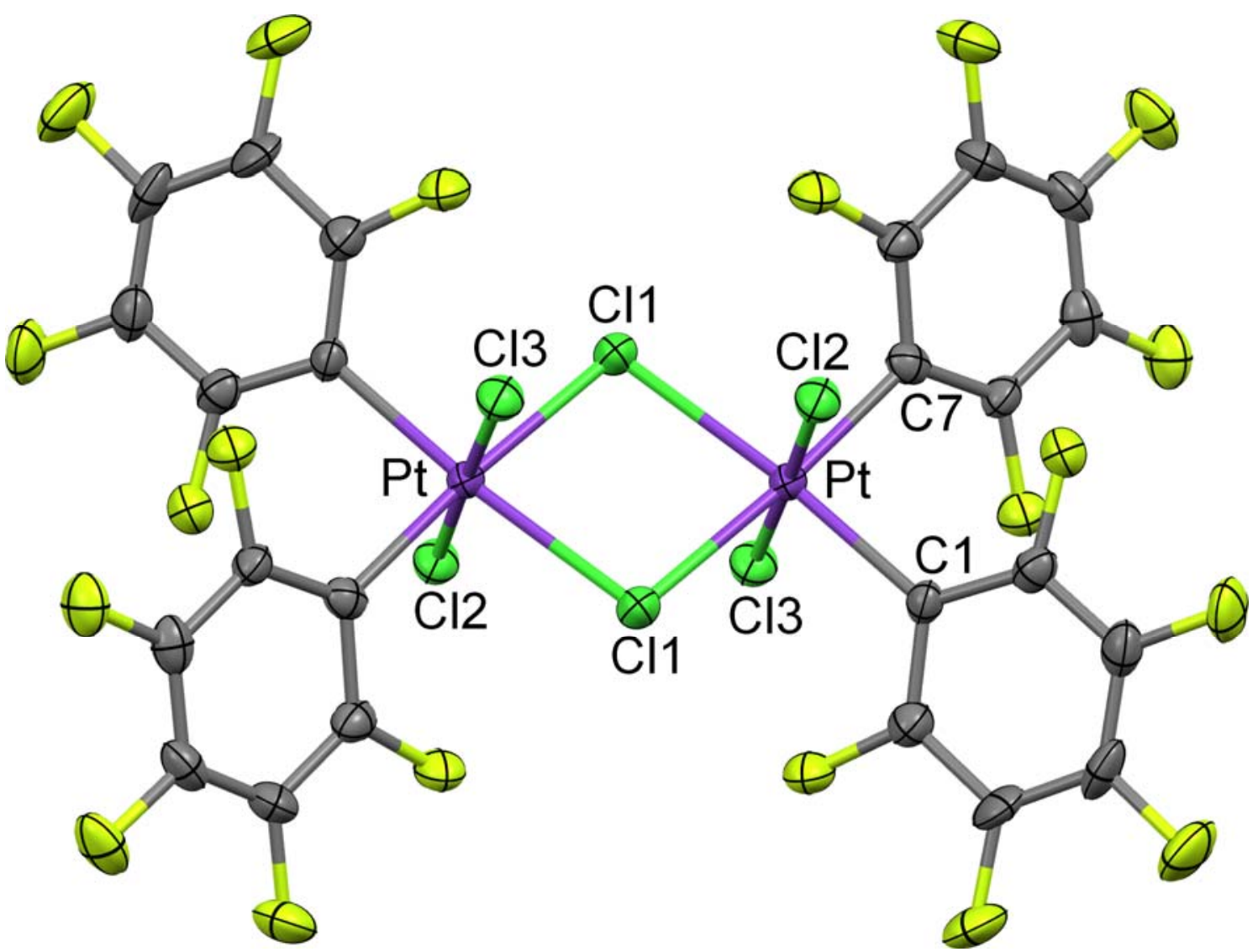

Figure 3. Molecular structure of the complex anion of $\left[\mathrm{NBu}_{4}\right]_{2}\left[\mathrm{Pt}_{2}(\mu-\mathrm{Cl})_{2} \mathrm{Cl}_{4}\left(\mathrm{C}_{6} \mathrm{~F}_{5}\right)_{4}\right](2)$.

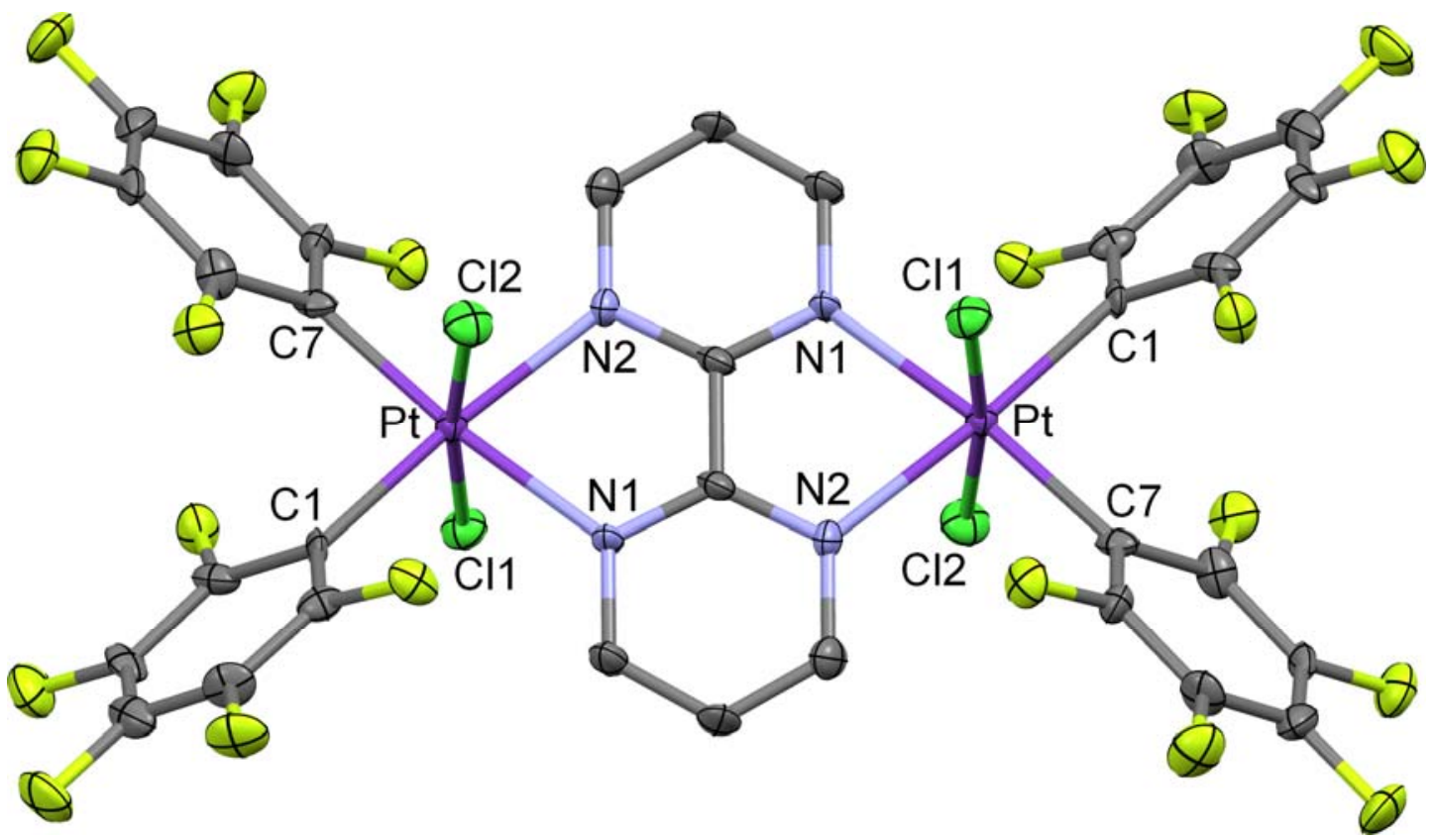

Figure 4. Molecular structure of the complex of $\left[\mathrm{Pt}_{2} \mathrm{Cl}_{4}\left(\mathrm{C}_{6} \mathrm{~F}_{5}\right)_{4}\left(\mu-\mathrm{C}_{8} \mathrm{~N}_{4} \mathrm{H}_{6}\right)\right] \cdot 4 \mathrm{Me} 2 \mathrm{CO}$ $\left(4 \cdot 4 \mathrm{Me}_{2} \mathrm{CO}\right)$. 


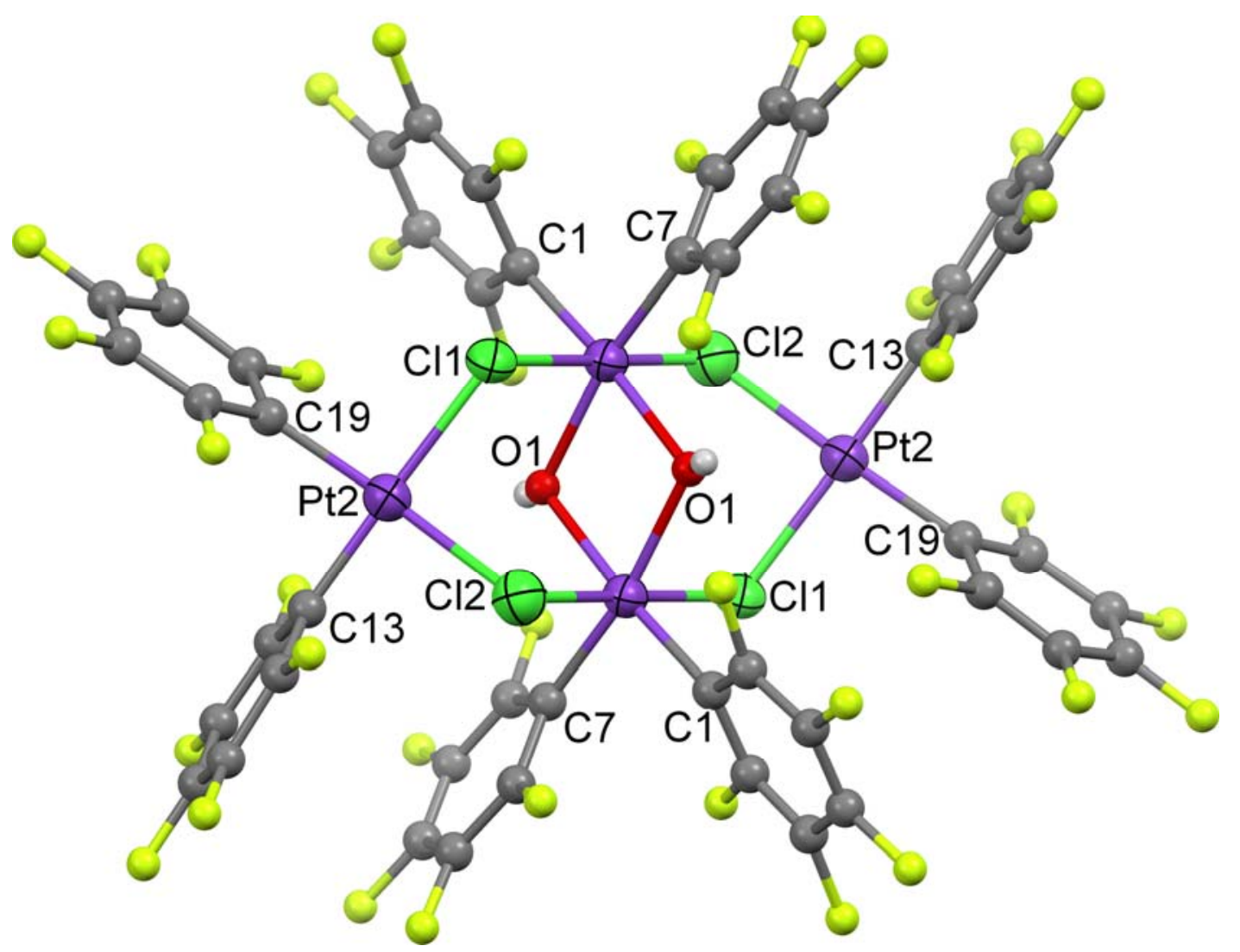

(a)

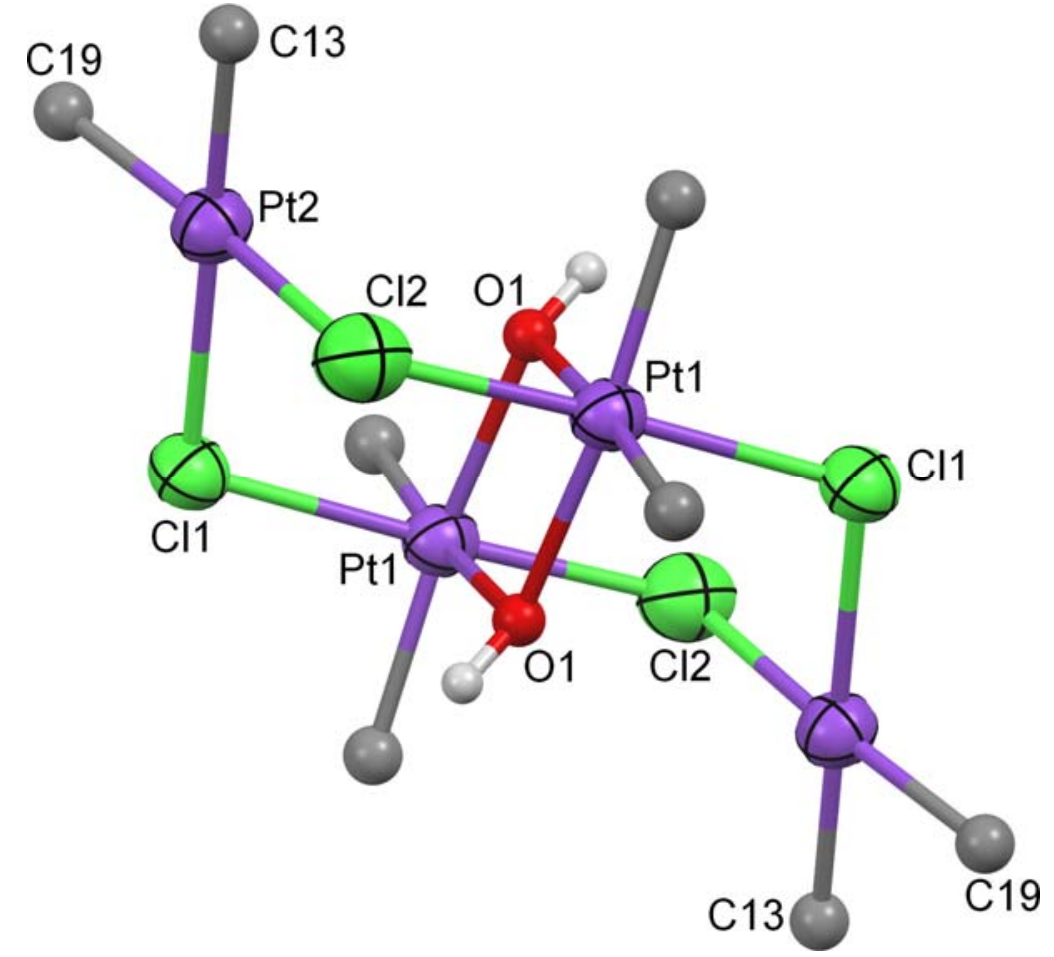

(b)

Figure 5. a) Molecular structure of the complex anion of $\left[\mathrm{NBu}_{4}\right]_{2}\left[\left\{\mathrm{Pt}(\mu-\mathrm{OH})\left(\mathrm{C}_{6} \mathrm{~F}_{5}\right)_{2}\right\}_{2}(\mu-\right.$ $\left.\mathrm{Cl})_{4}\left\{\mathrm{Pt}\left(\mathrm{C}_{6} \mathrm{~F}_{5}\right)_{2}\right\}_{2}\right] \cdot \mathrm{CH}_{2} \mathrm{Cl}_{2}\left(6 \cdot \mathrm{CH}_{2} \mathrm{Cl}_{2}\right)$. b) Detail of the core of the complex anion. 


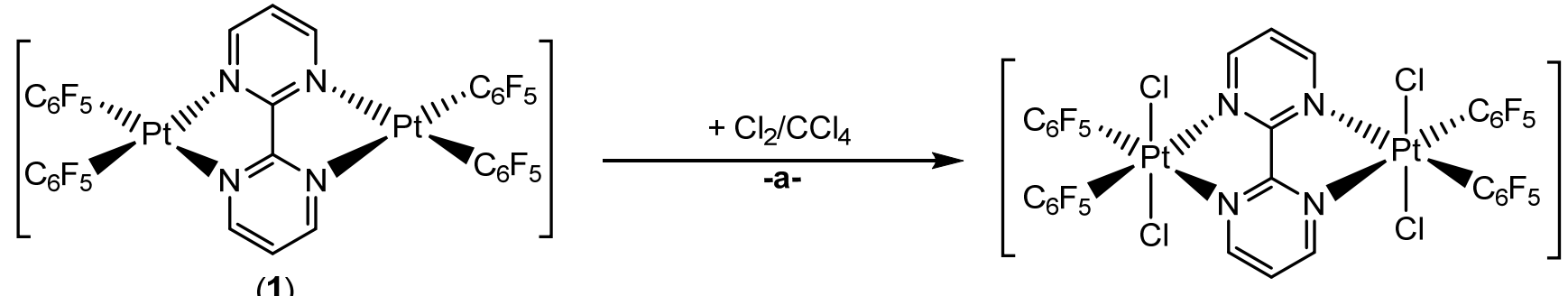

(1)

(4)

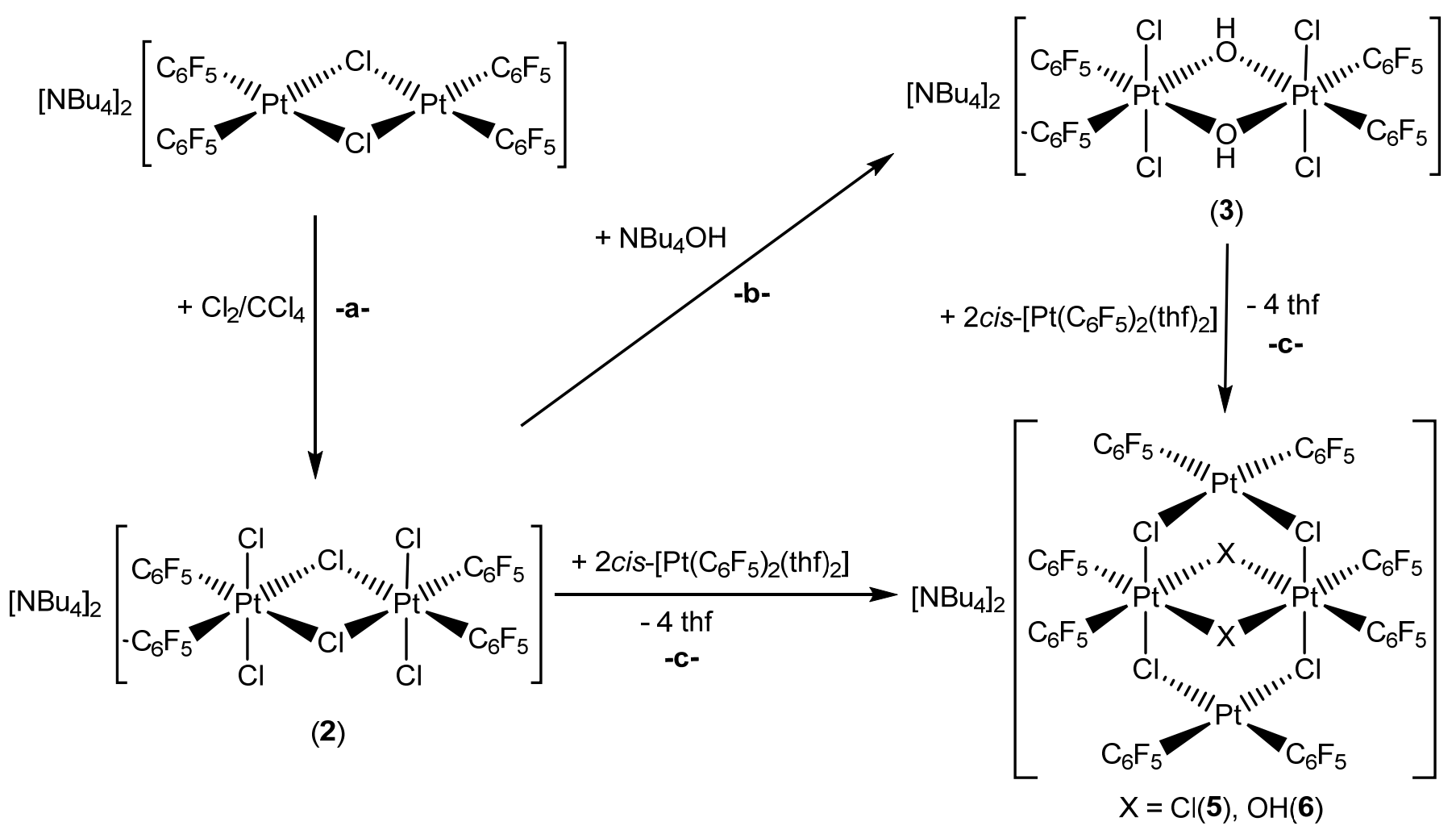

Scheme 1 
